\title{
Evaluation of coating Removal and Aggressive Surface Removal Surface Technologies Applied to Concrete Walls, Brick Walls, and Concrete Ceilings
}

\author{
Final Report \\ November 1997 \\ By: \\ M. A. Ebadian \\ L. E. Lagos
}

Work Performed Under Contract No.: DE-FG21-95EW55 ECEIVED

OCT 261998

For

OSTI

U.S. Department of Energy

Office of Fossil Energy

Federal Energy Technology Center

P.O. Box 880

Morgantown, West Virginia 26507-0880

By

Florida International University

Hemispheric Center for Environmental Technology (HCET)

Center for Engineering \& Applied Sciences

10555 West Flagler Street

EAS-2100

Miami, Florida 33174 


\section{Disclaimer}

This report was prepared as an account of work sponsored by an agency of the United States Government. Neither the United States Government nor any agency thereof, nor any of their employees, makes any warranty, express or implied, or assumes any legal liability or responsibility for the accuracy, completeness, or usefulness of any information, apparatus, product, or process disclosed, or represents that its use would not infringe privately owed rights. Reference herein to any specific commercial product, process, or service by trade name, trademark, manufacturer, or otherwise does not necessarily constitute or imply its endorsement, recommendation, or favoring by the United States Government or any agency thereof. The views and opinions of authors expressed herein do not necessarily state or reflect those of the United States Government or any agency thereof. 


\section{DISCLAIMER}

Portions of this document may be illegible in electronic image products. Images are produced from the best available original document. 


\section{ACKNOWLEDGMENT}

This research has been made possible with the financial support of the Fernald Environmental Management Project and the Mound Management Environmental Project. In addition, the authors would like to thank the HCET D\&D group for their support. Special thanks should go to Tanza Ross and Man Cheung for their efforts and commitment to this project. 


\section{TABLE OF CONTENTS}

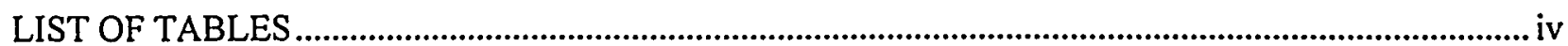

LIST OF FIGURES

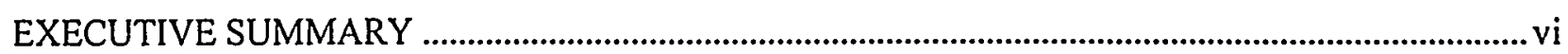

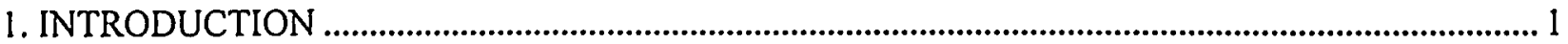

1.1 BACKGROUND OF THE FERNALD ENVIRONMENTAL MANAGEMENT PROJECT AND THE MOUND ENVIRONMENTAL

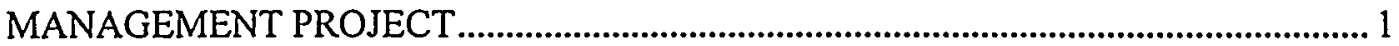

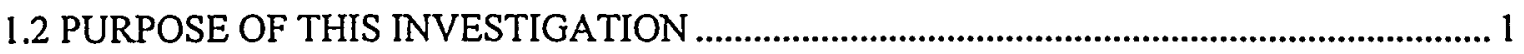

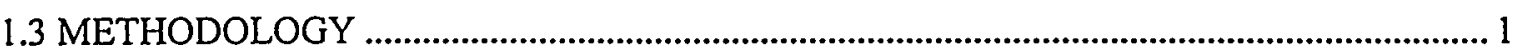

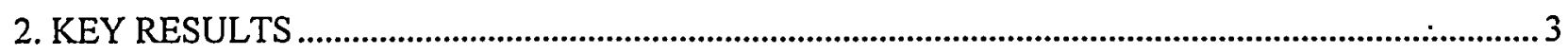

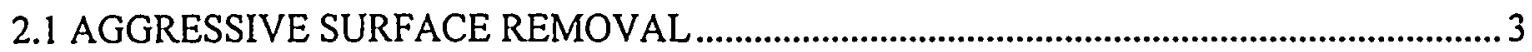

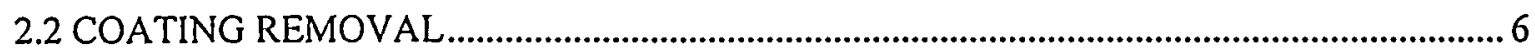

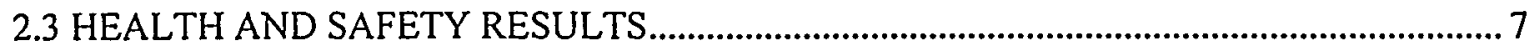

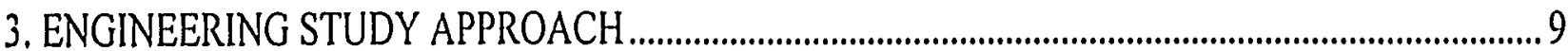

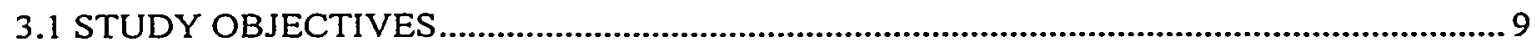

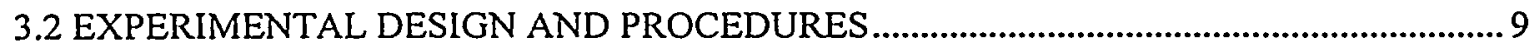

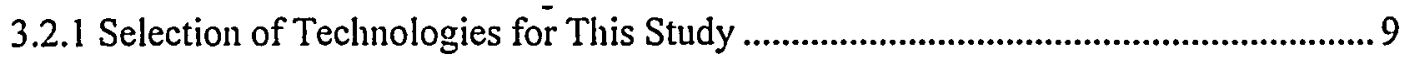

3.2.2 FIU-HCET Technology Assessment Site ............................................................. 10

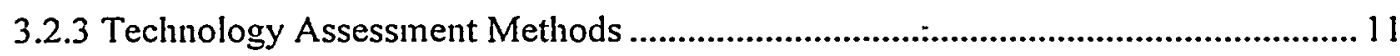

3.3 TECHNOLOGY ASSESSMENT DATA COLLECTED ...................................................... 12

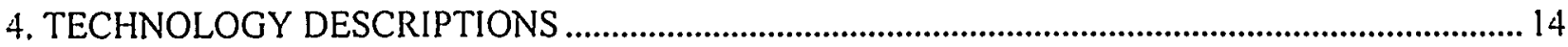

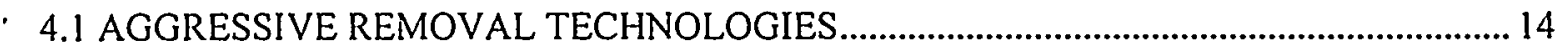

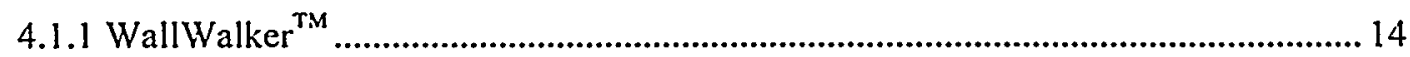

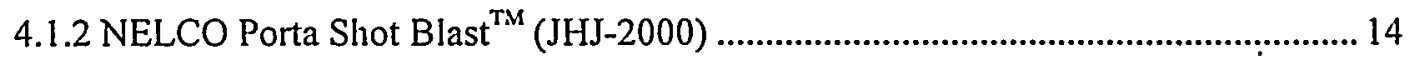

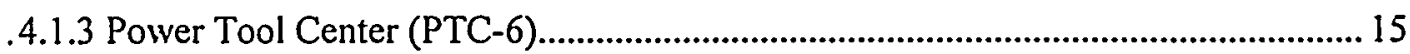

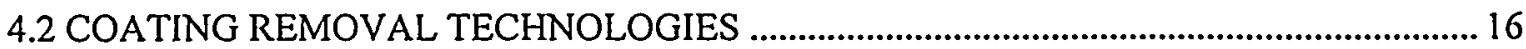

4.2.1 Pegasus Coating Removal System (PCRS-7)....................................................... 16

4.2.2 Advance Recyclable Media System (ARMS ${ }^{\text {TM }}$ )............................................... 17

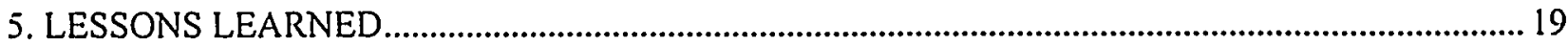

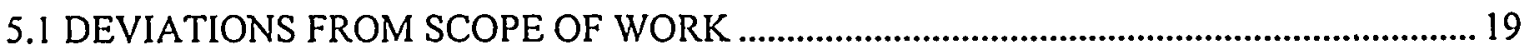

5.1.1 Deviation from Site Specifications..................................................................... 19

5.1.2 Technology Implementation Deviations .......................................................... 19

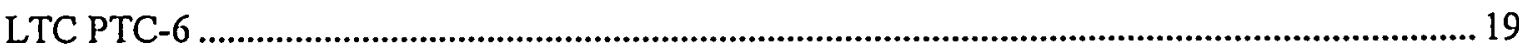

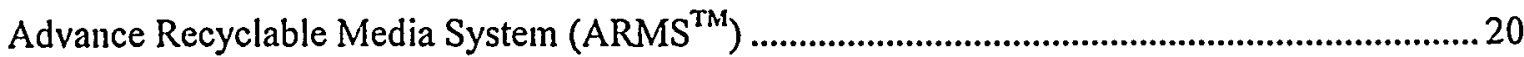

5.2 RECOMMENDATIONS FOR TECHNOLOGY ENHANCEMENT ....................................20

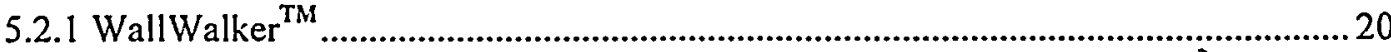


5.2.2 NELCO Porta Shot Blast ${ }^{\mathrm{TM}}$ Model JHJ-2000 .................................................. 21

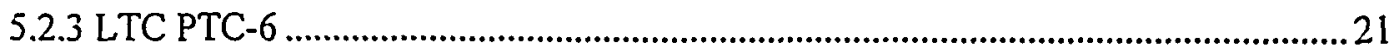

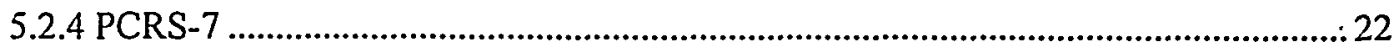

5.2.5 Advanced Recyclable Media System (ARMS ${ }^{\mathrm{TM}}$ )..............................................22

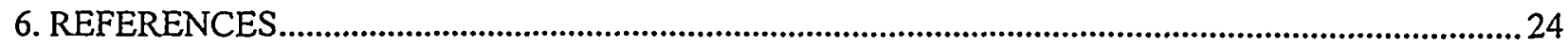

\section{APPENDIX A}

APPENDIX B

APPENDIX C

APPENDIX D

\section{LIST OF TABLES}

Table 1. Standard Deviation of Depth of Removal on the Various Surfaces .................................4

Table 2. Actual and Vendor Specified Removal Depth on Various Surfaces .................................5

Table 3. Removal Gaps Observed on the Various Surfaces .........................................................6

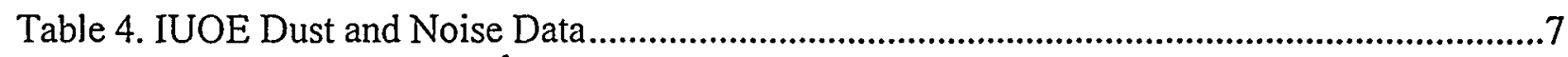

Table 5. Data Requirements and Sample Collection Methods ....................................................11 


\section{LIST OF FIGURES}

Figure 1. Average depth of removal by aggressive surface removal technologies........................3

Figure 2. Production rates of the aggressive surface removal technologies ...................................4

Figure 3a.FIU-HCET technology assessment site schematic..................................................9

Figure 3b.FIU-HCET technology assessment site. Note the coated concrete wall (foreground) and uncoated concrete wall (background) .....................................9

Figure 4. WallWalker ${ }^{\mathrm{TM}}$ with jib structure setup on uncoated concrete wall...............................13

Figure 5. WallWalker ${ }^{\mathrm{TM}}$ with mounting bracket setup on coated concrete wall............................13

Figure 6. Rear view of operator using the NELCO Porta Shot Blast ${ }^{\mathrm{TN}}$ (JHJ-2000) on a coated wall. Note the waste collection drum (left) and Nilfisk vacuum with HEPA filter (right) ......................................................................14

Figure 7. Side view of operator using the NELCO Porta Shot Blast ${ }^{\mathrm{Tu}}$ (JHJ-2000) .....................14

Figure 8. An operator using the PTC-6 with Roto-Peen equipped with Starcutter metal wheels. Note the PTC-6 waste collection system with the SWATS $^{\text {in }}$ drum beneath the dust chamber.

Figure 9. Attachments used with the LTC PTC-6. Shown from left to right:

Scaler Hammer, Roto-Peen equipped with Starcutter metal wheels, and Needle Gun.

Figure 10. Operating equipment for PCRS-7 spray application. From left to right: air compressor, paint sprayer, and sprayer nozzle.

Figure 11.Coated ceiling following treatment with PCRS-7 ................................................16

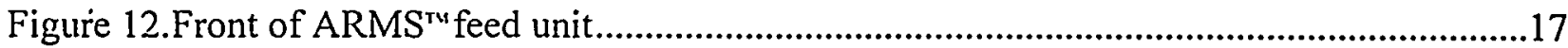

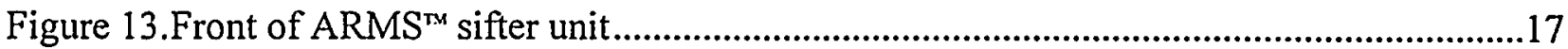




\section{EXECUTIVE SUMMARY}

The treatment of radioactively contaminated concrete surfaces is a concern during the decontamination and decommissioning (D\&D) process. As buildings undergo the $D \& D$ process, concrete floors, walls, and ceilings contaminated with radionuclides such as uranium, thorium, tritium, plutonium-238 and technetium-99 must be decontaminated before final disposal [1]. This project tests and evaluates commercially available and innovative technologies for the aggressive removal of $1 / 4$ to one inch of surface from concrete and brick walls, and the removal of coatings from concrete walls and ceilings. This investigation supports the U.S. Department of Energy (DOE) objectives of reducing risks to the environment and human health in support of its restoration projects at Fernald Environmental Management Project (FEMP) and Mound Environmental Management Project (MEMP). This project was performed at the Hemispheric Center for Environmental Technology (HCET) at Florida International University (FIU) where one innovative, and four commercially available decontamination technologies were evaluated under standard, non-nuclear testing conditions. The performance data generated by this project will assist DOE site managers in the selection of the safest, most efficient, and most costeffective decontamination technologies to accomplish their remediation objectives.

The aggressive surface removal technologies tested were as follows:

Pentek's WallWalker ${ }^{\mathrm{rM}}$. This innovative robotic scabbling technology removed an average of $1 / 3$ inch of coated concrete wall surface at a rate of 6.5 square feet per hour.

NELCO's Porta Shot Blast ${ }^{\mathrm{TN}}$ (JHJ-2000). This centrifugal shot blasting technology removed an average $1 / 14$ inch of coated brick wall surface at a rate of 17.05 square feet per hour.

LTC's PTC-6. This scabbling technology removed an average 1/13 inch of uncoated concrete wall surface at a rate of 11.9 square feet per hour.

The coating removal technologies tested were as follows:

Pegasus' PCRS-7. This chemical coating removal system did not remove the coating.

Surface Technology System's Advanced Recyclable Media System (ARMS'). This sponge blasting technology removed coating of concrete ceiling at a rate of 127.0 square feet per hour. 


\section{INTRODUCTION}

\subsection{BACKGROUND OF THE FERNALD ENVIRONMENTAL MANAGEMENT PROJECT AND THE MOUND ENVIRONMENTAL MANAGEMENT PROJECT}

The Fernald Environmental Management Project (FEMP), formerly known as the Feed Materials Production Center, was one of the main U.S. Department of Energy (DOE) facilities producing high-purity uranium metal products for use by different federal agencies. The Mound Environmental Management Project (MEMP) facility was one of the main DOE locations involved in research and development, engineering, production, and surveillance of components for DOE nuclear weapons; separation, purification, and sales of stable isotopes; and conducting DOE programs in nuclear safeguards and waste management, heat-source testing, and fusion fuel system. Production activities at the FEMP and MEMP facilities ceased in 1989 and 1991, respectively. However, during the operation periods at these sites, many buildings, and facilities, and equipment associated with production were contaminated to varying degrees. The majority of concrete material is considered to be radiologically contaminated from $1 / 2$ inch to one inch below the surface. Primary radiological contaminants found at the Fernald site include uranium, thorium, and technetium-99. The Mound site primarily has uranium, thorium, tritium, and plutonium-238 contaminants. In accordance with the requirements of the Comprehensive Environmental Response, Compensation, and Liability Act of 1980 (CERCLA), the highest priority mission at the Fernald and Mound sites is environmental restoration to reduce risks to human health and the environment as expediently as possible.

\subsection{PURPOSE OF THIS INVESTIGATION}

The purpose of this investigation was to test and evaluate innovative and commercially available technologies for the surface decontamination of walls and ceilings. This investigation supports the DOE's objectives of reducing risks to human health and the environment through its restoration projects at FEMP and MEMP. This project was performed at the Hemispheric Center for Environmental Technology (HCET) at Florida International University (FIU), where one innovative and four commercially available decontamination technologies were evaluated under standard, non-nuclear testing conditions. The performance data generated by this project will assist DOE site managers in the selection of the safest, most efficient, and most cost-effective decontamination technologies to accomplish their remediation objectives.

\subsection{METHODOLOGY}

FIU-HCET provided a test site where various types of surfaces were constructed to simulate walls and ceilings found at FEMP and MEMP. A list of technologies was compiled from the vendors who responded to the Commerce Business Daily advertisement; after consultations with FEMP and MEMP, vendors were invited to participate in the bidding process. Five technologies were then selected to participate in this project. Vendors demonstrated their decontamination 
technologies on identical surfaces while FIU-HCET evaluators collected performance data. Representatives from the International Union of Operating Engineers (IUOE) were present during technology demonstrations to assess health and safety factors. A separate report will be generated by IUOE based on their evaluation of these factors. 


\section{KEY RESULTS}

This section provides an overview of some of the most significant performance data obtained during this project.

\subsection{AGGRESSIVE SURFACE REMOVAL}

Figure 1 presents a summary of the average depth of removal attained by each of the aggressive technologies tested on the various surfaces. Table 1 presents the standard deviation of removal depth on the various surfaces. Figure 2 presents the production rates of the aggressive surface removal technologies in square feet per hour. Table 2 presents the actual and vendor specified removal depths on various surfaces. Table 3 presents the removal gaps observed on the various surfaces. The most appropriate technology for a particular project and site must be determined by the integration of many factors with the factor that is the most important for a particular site (e.g., production rate, cost. health and safety, and secondary waste generation).

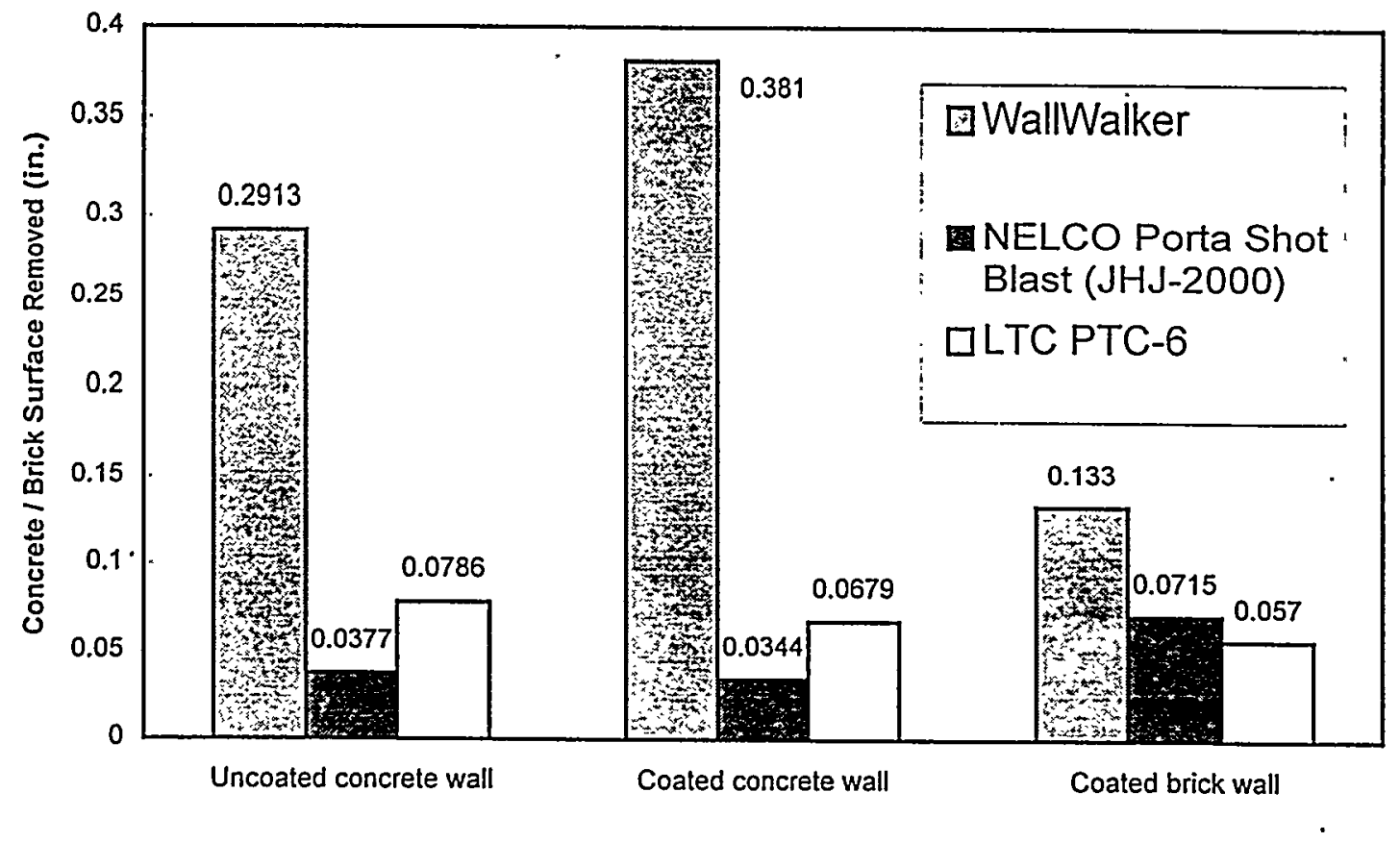

Figure 1. Average depth of removal achieved by aggressive surface removal technologies. 
Table 1.

Standard Deviation of Depth of Removal on the Various Surfaces

\begin{tabular}{|l|l|c|c|}
\hline \multirow{2}{*}{ Technology } & \multicolumn{1}{|c|}{ Surface Type } & $\begin{array}{c}\text { Average Depth of } \\
\text { Removal (in.) }\end{array}$ & $\begin{array}{c}\text { Standard } \\
\text { Deviation }\end{array}$ \\
\hline \multirow{4}{*}{ WallWalker } & Uncoated Concrete & 0.2913 & \pm 0.0910 \\
\cline { 2 - 4 } & Coated Concrete & 0.3810 & \pm 0.1966 \\
\cline { 2 - 4 } & Coated Brick & 0.1330 & \pm 0.0640 \\
\hline \multirow{2}{*}{$\begin{array}{l}\text { Shot BO Porta } \\
\text { JHJ-2000 }\end{array}$} & Uncoated Concrete & 0.0377 & \pm 0.0168 \\
\cline { 2 - 4 } & Coated Concrete & 0.0354 & \pm 0.0316 \\
\cline { 2 - 4 } & Coated Brick & 0.0715 & \pm 0.0382 \\
\hline \multirow{3}{*}{ LTC PTC-6 } & Uncoated Concrete & 0.0786 & \pm 0.0314 \\
\cline { 2 - 4 } & Coated Concrete & 0.0679 & \pm 0.0229 \\
\cline { 2 - 4 } & Coated Brick & 0.0570 & \pm 0.0438 \\
\hline
\end{tabular}

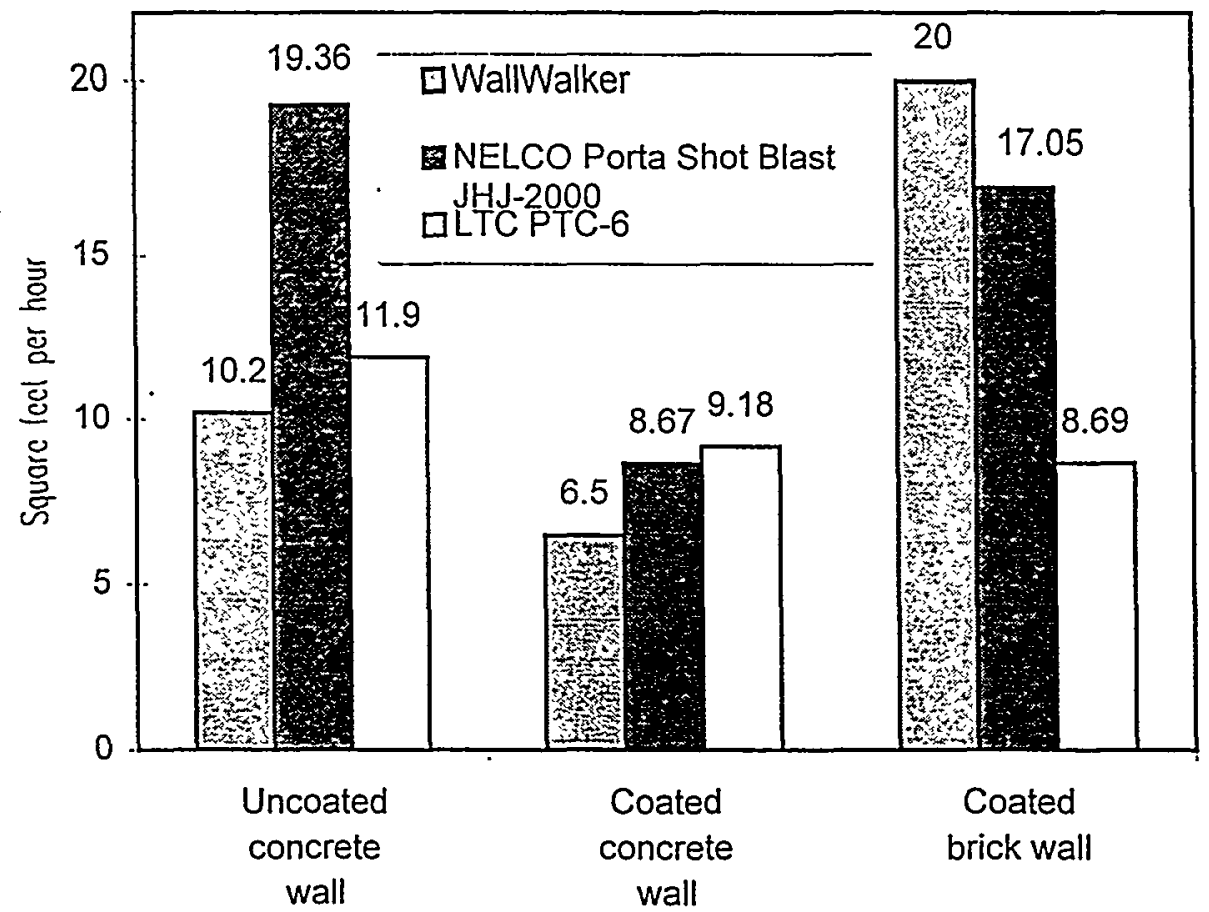

Figure 2. Production rates, in square feet per hour, achieved by the aggressive surface removal technologies. 
Table 2.

Actual and Vendor Specified Removal Depth on Various Surfaces

\begin{tabular}{|c|c|c|}
\hline Technology & $\begin{array}{c}\text { Actual Average } \\
\text { Removal Depth (inch) }\end{array}$ & $\begin{array}{c}\text { Removal Depth } \\
\text { Specified by Vendor }\end{array}$ \\
\hline WallWalker $^{\text {nt }}$ & $\begin{array}{l}\text { Uncoated concrete wall: } 0.2913 \\
\text { Coated concrete wall: } 0.381 \\
\text { Coated brick wall: } 0.133\end{array}$ & $\begin{array}{l}1 / 2 \text { inch, }(0.50 \text { inch }) \text { on } \\
\text { concrete walls } \\
1 / 4 \text { inch, }(0.25 \text { inch }) \text { on brick } \\
\text { walls }\end{array}$ \\
\hline $\begin{array}{l}\text { Nelco Porta Shot } \\
\text { Blast }^{\text {Th }} \text { (model JHJ- } \\
\text { 2000) }\end{array}$ & $\begin{array}{l}\text { Uncoated concrete wall: } 0.0377 \\
\text { Coated concrete wall: } 0.0344 \\
\text { Coated brick wall: } 0.0715\end{array}$ & $\begin{array}{l}1 / 4 \text { inch, }(0.250 \text { inch }) \text { on } \\
\text { concrete walls } \\
1 / 8 \text { inch, }(0.125 \text { inch }) \text { on } \\
\text { brick walls }\end{array}$ \\
\hline LTC PTC-6 & $\begin{array}{l}\text { Uncoated concrete wall: } 0.0786 \\
\text { Coated concrete wall: } 0.0679 \\
\text { Coated brick wall: } 0.0570\end{array}$ & $\begin{array}{l}1 / 2 \text { inch, }(0.50 \text { inch }) \text { on } \\
\text { concrete walls } \\
1 / 4 \text { inch, }(0.250 \text { inch }) \text { on brick } \\
\text { walls }\end{array}$ \\
\hline PCRS-7 & $\begin{array}{l}\text { Coated concrete wall and ceiling; } \\
\text { did not remove the coating }\end{array}$ & coating removal \\
\hline $\operatorname{ARMS}^{\text {Tx }}$ & $\begin{array}{l}\text { Coated concrete wall and ceiling; } \\
\text { removed the coating }\end{array}$ & coating removal \\
\hline
\end{tabular}


Table 3.

Removal Gaps Observed on the Various Surfaces

\begin{tabular}{|c|c|c|c|c|c|}
\hline Technology & Wall surfaces & $\begin{array}{l}\text { Ceiling to } \\
\text { wall } \\
\text { interface } \\
\text { (inch) }\end{array}$ & $\begin{array}{l}\text { Floor to } \\
\text { wall } \\
\text { interface } \\
\text { (inch) }\end{array}$ & $\begin{array}{l}\text { Wall to wall } \\
\text { interface } \\
\text { [Left side] } \\
\text { (inch) }\end{array}$ & $\begin{array}{c}\text { Wall to } \\
\text { wall } \\
\text { interface } \\
\text { [Right side] } \\
\text { (inch) } \\
\end{array}$ \\
\hline \multirow{3}{*}{ WallWalker $^{\text {TM }}$} & uncoated concrete & $231 / 4$ & $61 / 2$ & no wall & 24 \\
\hline & coated concrete & $351 / 4$ & 7 & no wall & $10 \mathrm{r} / 2$ \\
\hline & coated brick & $73 / 4$ & $77 / 8$ & no wall & 21 \\
\hline \multirow{3}{*}{$\begin{array}{l}\text { NELCO Porta } \\
\text { Shot Blast } \\
\text { (JHJ-2000) }\end{array}$} & uncoated concrete & $43 / 4$ & $61 / 2$ & 11 & no wall \\
\hline & coated concrete & $61 / 4$ & $91 / 4$ & $117 / 8$ & no wall \\
\hline & coated brick & 2 & $91 / 2$ & 11 & no wall \\
\hline LTC PTC-6 & $\begin{array}{l}\text { uncoated concrete } \\
\text { coated concrete } \\
\text { coated brick }\end{array}$ & $\begin{array}{l}\text { no gaps on } \\
\text { all surfaces }\end{array}$ & $\begin{array}{l}\text { no gaps on } \\
\text { all surfaces }\end{array}$ & $\begin{array}{l}\text { no gaps on } \\
\text { all surfaces }\end{array}$ & $\begin{array}{l}\text { no gaps on } \\
\text { all surfaces }\end{array}$ \\
\hline
\end{tabular}

\subsection{COATING REMOVAL}

The PCRS-7 chemical coating removal system was demonstrated by Pegasus International and the Advanced Recyclable Media System (ARMS ${ }^{\text {Tu }}$ ) was demonstrated by Surface Technology System. Theșe tests were performed during the same period of time as the aggressive removal technologies. These data are valuable information for site personnel requiring a lesser degree of surface removal or for delicate surfaces where damage to the substrate is not desirable.

The PCRS-7 chemical coating removal did not remove the coating and no production rate was determined. The reasons why the chemical did not remove the coating were not determined. A previous test of the PCRS-5 was effective in removing the coating from the concrete floor in an open area. A speculative reason could be that the wall and ceiling surfaces were not exposed to sunlight and the surfaces were enclosed. The ARMS ${ }^{\text {Tn }}$ technology test results are as follows:

- The $\mathrm{ARMS}^{\mathrm{Ta}}$ absolute production rate on the coated concrete wall based on multiple passes: $43.92 \mathrm{ft}^{2}$ per hour.

- The $\mathrm{ARMS}^{\mathrm{TH}}$ absolute production rate on the coated ceiling based on one pass: $127.0 \mathrm{ft}^{2}$ per hour.

The lowered production rate on the coated concrete wall was due to an additional Ply-Mastic primer on the wall. Surface Technology System's operator performed multiple passes on the 
coated wall to remove the primer. On additional passes intended to remove the primer, the media was hitting the concrete and generating large amounts of dust particles. Operators performed one pass on the coated ceiling to minimize the generation of dust. See Appendix A for the definition of absolute production rate.

\subsection{HEALTH AND SAFETY RESULTS}

The IUOE was responsible for taking health and safety-related data during the technology demonstrations.

Table 4 presents a summary of the dust and noise level from the IUOE draft report. Please contact the IUOE at (304) 253-8670 to obtain the detailed report. 
Table 4.

IUOE Dust and Noise Data

\begin{tabular}{|c|c|c|}
\hline Technology & Dust Level (mg/m $\left.{ }^{3}\right)$ & Noise Level (dB) \\
\hline WallWalker $^{r s}$ & $\begin{array}{l}\text { Level of } 0.0 \text { was recorded at area of } \\
\text { operators". } \\
\text { Level of } 64.9,46.7 \text {, and } 106.5 \text { were } \\
\text { recorded at scabbler head. }\end{array}$ & $\begin{array}{l}\text { Maximum levels observed during } \\
\text { sampling period at operator's station } \\
\text { was } 116.0,96.6,100.8 \text {, and } 99.6 \text {. } \\
\text { The highest instantaneous level was > } \\
140 \text {. }\end{array}$ \\
\hline $\begin{array}{l}\text { NELCO Porta } \\
\text { Shot Balst" } \\
\text { JHJ-2000 }\end{array}$ & $\begin{array}{l}\text { Operator } 1 \text { personal dust sampling } \\
\text { was 15.2. } \\
\text { Operator } 2 \text { personal dust sampling } \\
\text { was 16.6. }\end{array}$ & $\begin{array}{l}\text { Maximum levels observed during } \\
\text { sampling was }>116.6 \text { and } 106.7 \text { for } \\
\text { operator } 1 . \\
\text { Operator } 2 \text { observed } 104.3 \text { and } 108.4 \text {. }\end{array}$ \\
\hline LTC PTC-6 & $\begin{array}{l}\text { Operator } 1 \text { personal dust sampling } \\
\text { was } 28.6 \text {. } \\
\text { Operator } 2 \text { personal dust sampling } \\
\text { was } 30.82 \text {. }\end{array}$ & $\begin{array}{l}\text { Maximum levels observed during } \\
\text { sampling was } 116.4 \text { for operator } 1 \text { and } \\
114.7 \text { for operator } 2 \text {. } \\
\text { The peak exposure seen for operator } 1 \\
\text { was } 142.9 \text { and } 135.8 \text { for operator } 2 \text {. }\end{array}$ \\
\hline PCRS-7 & $\begin{array}{l}\text { (Organic vapor readings) } \\
\text { Up to } 1.5 \mathrm{ppm} \text { was observed during } \\
\text { removal of chemical. } \\
\text { Up to } 2.0 \mathrm{ppm} \text { was observed during } \\
\text { sprayer application of chemical. } \\
\text { Up to } 5.0 \mathrm{ppm} \text { was observed during } \\
\text { spatula application of chemical. }\end{array}$ & No noise results. \\
\hline $\mathrm{ARMS}^{\mathrm{TN}}$ & $\begin{array}{l}\text { Area sampling was performed. At the } \\
\text { end of each sampling period, } 1 / 4 \text { inch- } \\
3 / 4 \text { inch of visible dust was observed } \\
\text { on sampling filter. } \\
\text { Personal samples observed } 2729.8 \\
\text { for the operator shoveling blasting } \\
\text { media, and } 232.6 \text { for the operator of } \\
\text { the blasting nozzle. }\end{array}$ & $\begin{array}{l}\text { Maximum level observed during } \\
\text { sampling was } 129.2 \text { for operator } 1 \text { and } \\
136.9 \text { for operator } 2 \text {. } \\
\text { The highest instantaneous level was }> \\
140 \text {. }\end{array}$ \\
\hline
\end{tabular}

* Control unit was located approximately $15 \mathrm{ft}$. away from the scabbler head. 


\section{ENGINEERING STUDY APPROACH}

\subsection{STUDY OBJECTIVES}

The objective of this study was to perform comparative analyses of commercially available and innovative surface removal technologies applicable to the D\&D of FEMP's and MEMP's facilities. The bases for these comparative analyses included the following:

- End point achieved;

- Production rate; and

- Technology benefits and limitations.

\subsection{EXPERIMENTAL DESIGN AND PROCEDURES}

\subsubsection{Selection of Technologies for This Study}

Established sources and databases were used to categorize the technologies and perform the initial screening of technology types. These sources and databases included:

- DOE/EM-0142P Decommissioning Handbook [2];

- ORNL/M-2751 Oak Ridge National Laboratory Technology Logic Diagram [3];

- EGG-WTD-11104 Idaho National Engineering Laboratory Decontamination and Decommissioning Technology Logic Diagram [4];

- DOE/ORO/2034 Contaminated Concrete: Occurrence and Emerging Technologies for DOE Decontamination [5];

- Remedial Action Program Information Center (RAPIC) Database [6]; and

- Hemispheric Center for Environmental Technology Decontamination and Decommissioning Database [7].

The request for prospective bidders was advertised in the November 27, 1996 issue of Commerce Business Daily. Bidders were selected considering their number of years of work experience in nuclear decontamination, and references of previous work performed using the selected technology.

Considering the source and database review, qualified bids received, and input from FEMP and MEMP project engineers, the following innovative and commercially available technologies were tested:

- WallWalker ${ }^{\mathrm{nt}}$ [innovative];

- LTC PTC-6 [commercial]; 
- PCRS-7 [commercial];

- NELCO Porta Shot Blast ${ }^{\text {TH }}$ (JHJ-2000)[commercial]; and

- Advanced Recyclable Media System (ARMS ${ }^{\mathrm{TH}}$ ) [commercial].

\subsubsection{FIU-HCET Technology Assessment Site}

The FIU-HCET technology assessment site is shown in Figure 3. Each test bay consists of a concrete pad with 10-foot- high concrete or brick walls on three sides and, in some bays, a concrete ceiling covering half of the pad. All masonry walls, floors, and ceilings at the assessment site have a thickness of 8 inches. The brick walls were built onto concrete walls after the concrete walls were poured. Each test surface measures approximately 20 feet by 10 feet to yield an area of approximately 200 square feet.

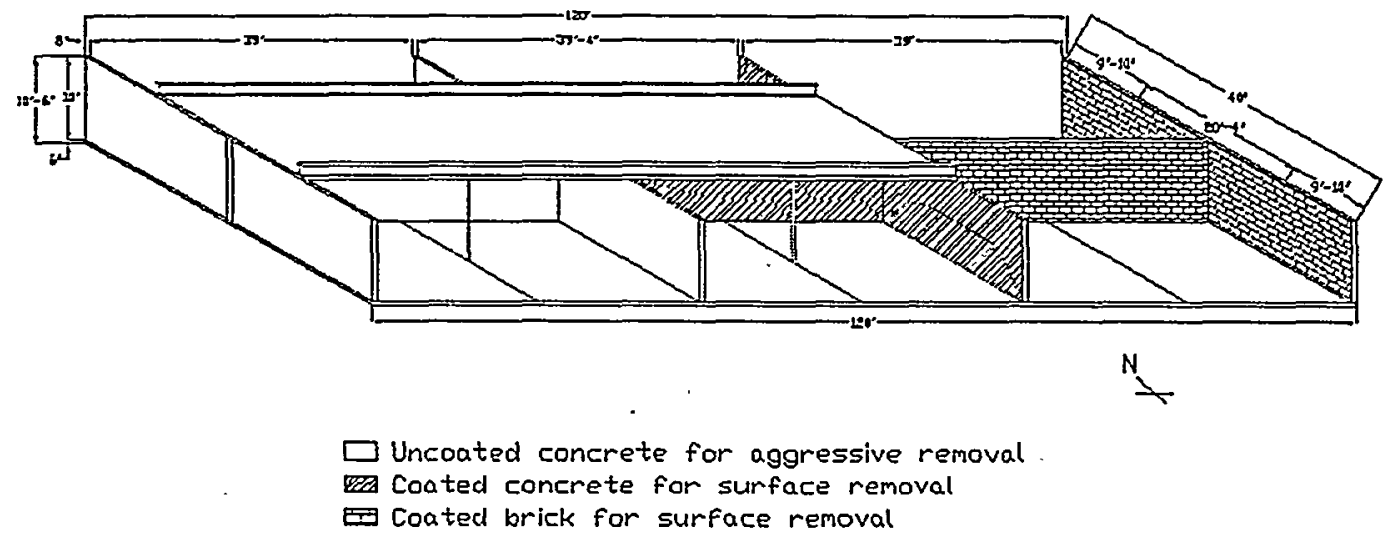

Figure 3a. FIU-HCET technology assessment site schematic.

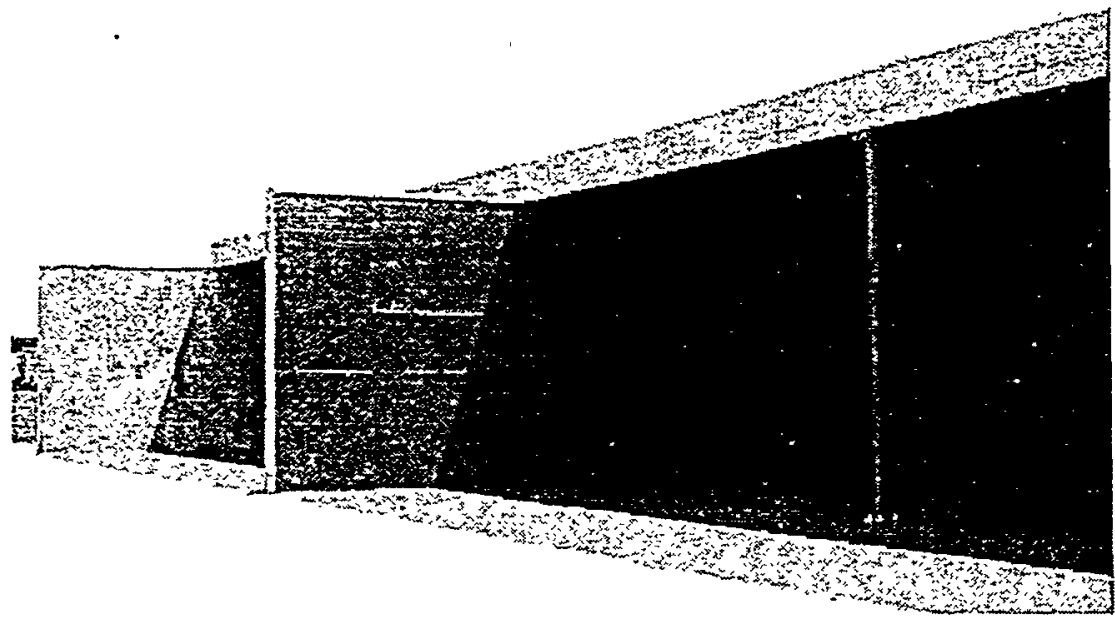

Figure 3b. FIU-HCET technology assessment site. Note the coated concrete wall (foreground) and uncoated concrete wall (background). 
A preliminary review of the FEMP and other DOE sites indicated wide variability in the composition and types of the concrete used. This variability complicated the selection of the proper mix design for the construction of the concrete test areas. A 4000-psi mix was specified [8]. After the concrete was poured, for 3,7 , and 28 days, compression tests were performed, yielding, after the 28 days, a concrete compressive strength minimum of 4000 psi on all testing areas.

The FIU-HCET technology assessment site is surrounded by a 6-foot-high chain link fence to provide security and restrict access to the area. A trailer and an air conditioned metal shed, which serves as a field office, changing facility and cool-down area for the vendor, HCET and IUOE representatives, are located adjacent to the assessment site test pads. During technology assessments, each test bay was covered by a tent with three side walls which served as a wind buffer and sun shield.

During construction of the walls, snap ties were used to hold the forms that shaped the wall together. After the concrete was set, the forms were removed exposing the snap ties on the surface of the concrete wall. The majority of the snap ties were cut as deep as 1 inch into the surface of the wall. However, some were left closer to the surfaces. The holes on the wall were patched with concrete after the snap ties were cut.

The selected coating was purchased from Michael A. Bruder \& Son Architectural Industrial Coatings. The coating determination was made using FEMP's paint specification for acid resistant surfaces. The coating applied to the brick wall, concrete wall and concrete ceiling consisted of one 8-mils-thick (wet) coat of Ply-Mastic primer, which dried to an approximate thickness of 7 mils. A 3-mils-thick (wet) finish coat of Ply-Thane 890 was then applied, which dried to an approximate thickness of $11 / 2$ mils. Material Safety Data Sheets (MSDS) were provided to vendors for waste characterization.

\subsubsection{Technology Assessment Methods}

\section{End point achieved}

Technology vendors demonstrated their respective technology in the manner that they deemed most efficient. The goal for the coating removal systems was complete coating removal. The goal for the aggressive surface removal system was removal of up to 1 inch of surface material. To determine the depth of surface removal, Precision Measuring Corp. performed a 200-point survey at 1-foot intervals on each test area for aggressive surface removal prior to the technology testing. After the testing, a second survey of the same 200 points was performed to determine the depth of removal. Only the points that had undergone aggressive surface removal were used to calculate the average depth of removal. The accuracy of the surveying instrument was \pm 0.01 inch.

\section{Production rates}

Production rates were determined by measuring the total surface area removed divided by the total number of hours of equipment operation required to complete the task. The site-specific production rate and the absolute production rate are defined in Appendix A. 


\section{Technology benefits and limitations}

Benefits and limitations were obtained by conducting field demonstrations and performing a literature search of the individual technologies. If a conflict existed between published information and field demonstration, the data obtained in the field testing were used.

\subsection{TECHNOLOGY ASSESSMENT DATA COLLECTED}

Data were collected by direct measurement and observation; by querying vendors and technologists; and from literature supplied by the vendors [9]. Table 5 presented below details the data requirements and the collection method employed during the technology evaluation.

Table 5. Data Requirements and Sample Collection Methods

\begin{tabular}{|l|l|}
\hline \multicolumn{1}{|c|}{ Data Requirements } & \multicolumn{1}{c|}{ Sample Collection Methods } \\
\hline \multicolumn{2}{|c|}{ GENERAL INFORMATION } \\
\hline Technology Description & Vendor supplied; field inspection \\
\hline Basic Equipment Description & Vendor supplied; field verification \\
\hline Support Equipment & Vendor supplied; field inspection \\
\hline \multicolumn{1}{|c|}{ COST DATA } \\
\hline Estimated Capital Cost & Vendor supplied \\
\hline Support Equipment Cost & Vendor supplied; outside reference sources \\
\hline Maintenance Cost & Vendor supplied \\
\hline Media Cost & Vendor supplied \\
\hline
\end{tabular}


Table 5. Data Requirements and Sample Collection Methods (Continued)

\begin{tabular}{|l|l|}
\hline \multicolumn{2}{|c|}{ OPERATIONAL DATA } \\
\hline Production Rate & Field calculation \\
\hline End Point Achieved & Outside reference source (survey) \\
\hline Labor Classification & Vendor supplied; field verification \\
\hline Benefits & Vendor supplied; field verification \\
\hline Limitations & Vendor supplied; field verification \\
\hline Media Type & Vendor supplied; field verification \\
\hline Media Quantity & Vendor supplied; field verification \\
\hline Utility Requirements & Vendor supplied; field verification \\
\hline Environmental Conditions & Field observation; outside reference source \\
\hline Waste Management & Vendor supplied; field inspection \\
\hline \multicolumn{1}{|c|}{ Primary/Secondary Waste Condition } & Field observation \\
\hline \multicolumn{1}{|c|}{ Primary/Secondary Waste Volume (fif $/ \mathrm{ft}^{2}$ ) } & Field calculation \\
\hline \multicolumn{1}{|c|}{ Secondary Waste Characteristics } & Field observation \\
\hline Equipment Portability & Vendor supplied; field verification \\
\hline Operation/Maintenance Requirements & Vendor supplied; field verification \\
\hline & IMPLEMENTATION DATA \\
\hline Equipment Availability & Vendor supplied \\
\hline References & Vendor supplied; outside reference source \\
\hline Health and Safety Concerns & Vendor supplied; field observation (IUOE*) \\
\hline
\end{tabular}

* International Union of Operating Engineers 


\section{TECHNOLOGY DESCRIPTIONS}

\subsection{AGGRESSIVE REMOVAL TECHNOLOGIES}

\subsubsection{WallWalker ${ }^{\text {Ts }}$}

The WallWalker ${ }^{\mathrm{TM}}$ robotic scabbler consists of a motion control system and a scabbler head. The motion control system controls the position, velocity and acceleration of the scabbler head over a vertical surface. This system works by independently controlling the lengths of two separate cables that may be attached to the left and right sides of the wall by mounting brackets, or alternately may be secured to a free-standing jib structure. The scabbler head uses a new lowfriction static seal that maintains vacuum flow while maximizing the vacuum pressure between the scabbler head and the wall. The scabbler head houses three pistons, each mounted on an independent suspension to allow for surface height fluctuations and to maintain optinum normal force on the wall. The three piston heads are designed to rotate about a central axis perpendicular to the wall as the scabbler head travels across the wall. The scabbler head has three wheels that allow it to move across the vertical surface. Figures 4 and 5 show the jib structure setup and mounting brackets setup, respectively.

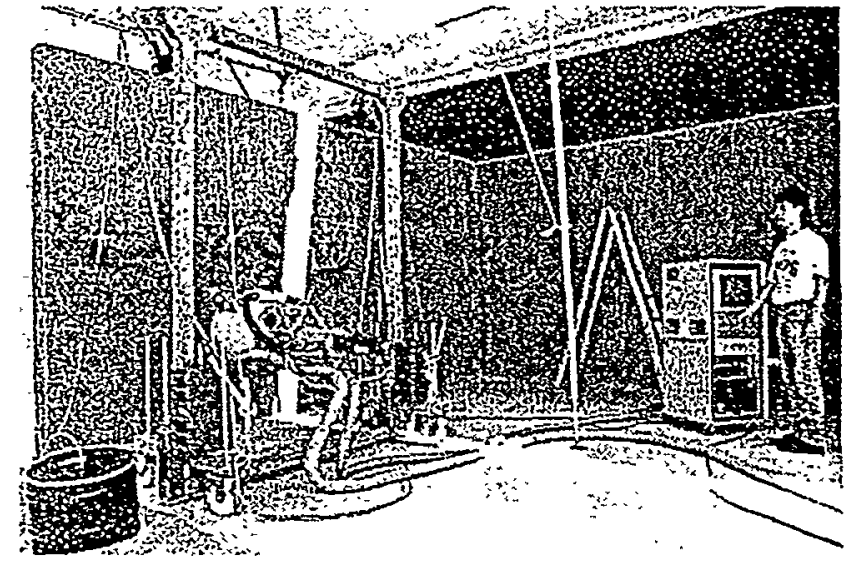

Figure 4. WallWalker" with jib structure setup on uncoated concrete wall.

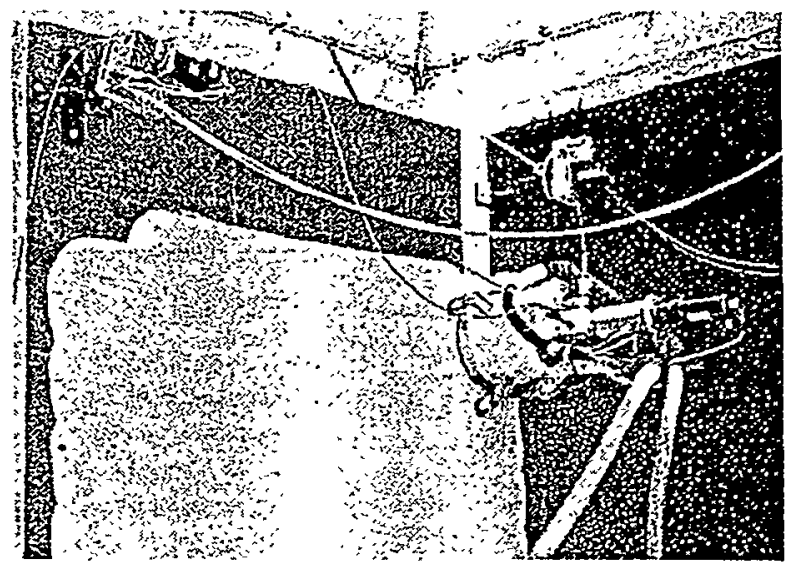

Figure 5. WallWalker ${ }^{\text {tx }}$ with mounting bracket setup on coated concrete wall.

\subsubsection{NELCO Porta Shot Blast ${ }^{\mathrm{nt}}$ (JHJ-2000)}

NELCO manufactures 12 different Porta Shot-Blast machines that are custom-configured to meet users specific requirements. NELCO portable shot blasting machines are available in a wide range of sizes to suit most surface preparation requirements. NELCO's patented blast wheel 
design produces a uniform blast pattern, resulting in a smooth, uniform surface profile with no hot spots or grooves as are produced by blasters with center-fed wheel designs. Machines are available for indoor and outdoor use, can be used on vertical or horizontal surfaces, and are powered by propane, diesel, gasoline, electric, or pneumatic engines. NELCO will custom-build shot blasters to suite specific customer requirements.

The NELCO Porta Shot Blast ${ }^{\mathrm{TN}}$ (JHJ-2000) is a hand-held portable steel shot blaster. This unit has a $1 " \times 1.7$ " blast pattern and a $1 / 2$ HP electric/pneumatic motor. The debris accumulates in the dust collector and the shot accumulates in the hopper, after rebounding from the work surface. Gravity then pulls the shot into the impeller where it is recycled. The blaster holds approximately 2 pounds of shot. Horizontal, vertical, and overhead hoppers are included. This unit is also equipped with a dual safety shut-off valve. Figures 6 and 7 show the NELCO Porta Shot Blast ${ }^{\text {th }}$ $\mathrm{JHJ}-2000$ in operation.

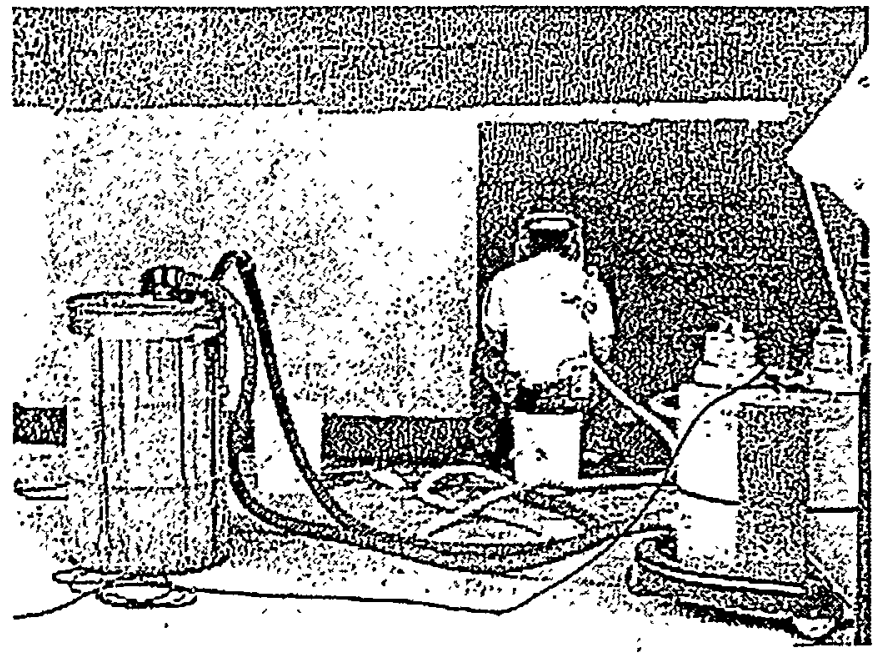

Figure 6. Rear view of operator-using the NELCO Porta Shot Blast ${ }^{\text {Tx }}(\mathrm{JHJ}-2000)$ on a coated wall. Note the waste collection drum (left) and Nilfisk vacuum with HEPA filter (right).

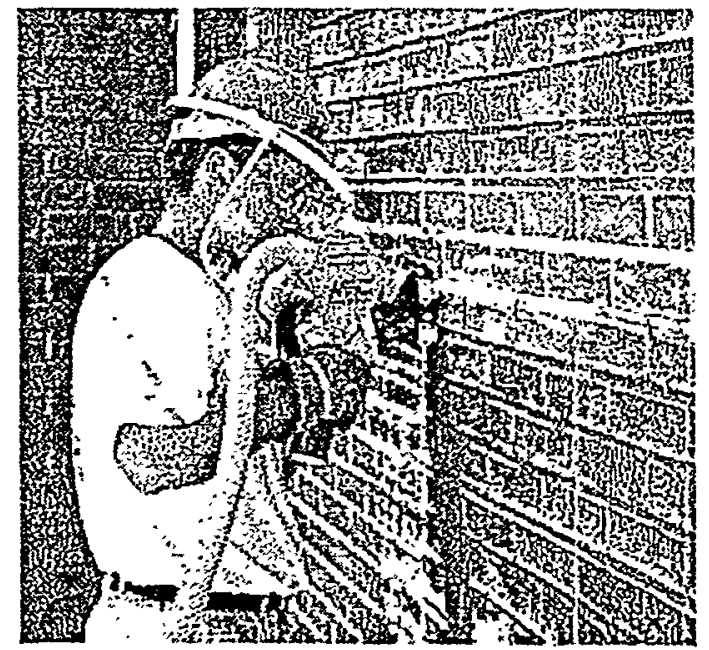

Figure 7. Side view of operator using the NELCO Porta Shot Blast ${ }^{\mathrm{TM}}$ (JHJ-2000).

\subsubsection{Power Tool Center (PTC-6)}

The LTC PTC-6 uses compressed air from an air source connected via air hoses to the control panel, which connects to the individual units to regulate the air pressure. The decontamination tools use air pressure to pound or cut the paint from the surface. A separate compressed air flow powers the vacuum generator which is regulated by the control panel. The vacuum generator creates a vacuum connected to the power tools and leading to the dust chamber (which is locater inside the SWATS" drum) to collect the dust and paint chips from the surface being 
decontaminated. A third compressed air flow cleans the filters by pulsing air through a pipe with slots. The blasts of air shake the dust and debris from the filter fabric. The recommended vacuum working pressure is 120 psi under full operational flow. Figures 8 and 9 show the PTC-6 and the decontamination tools used for the demonstration.

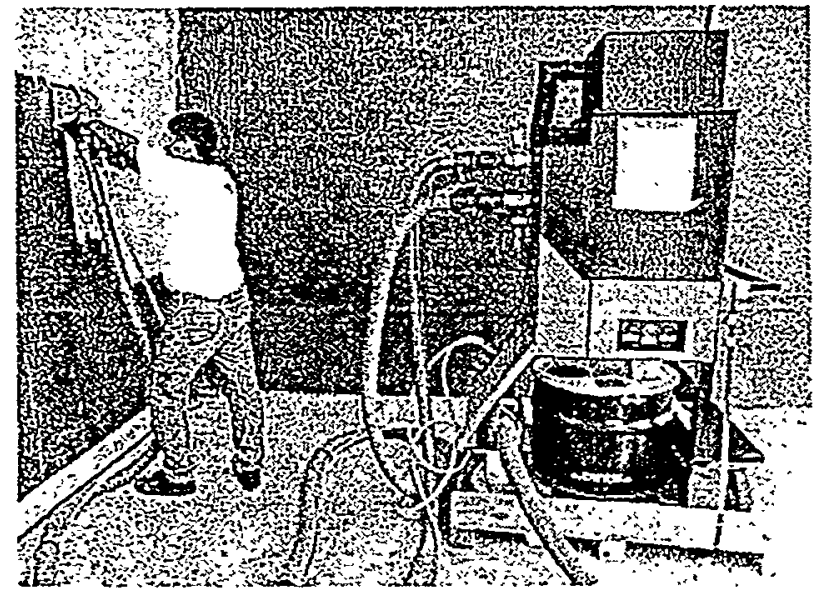

Figure 8. An operator using the PTC-6 with RotoPeen equipped with Starcutter metal wheels. Note the PTC-6 waste collection system with the SWATS drum beneath the dust chamber.

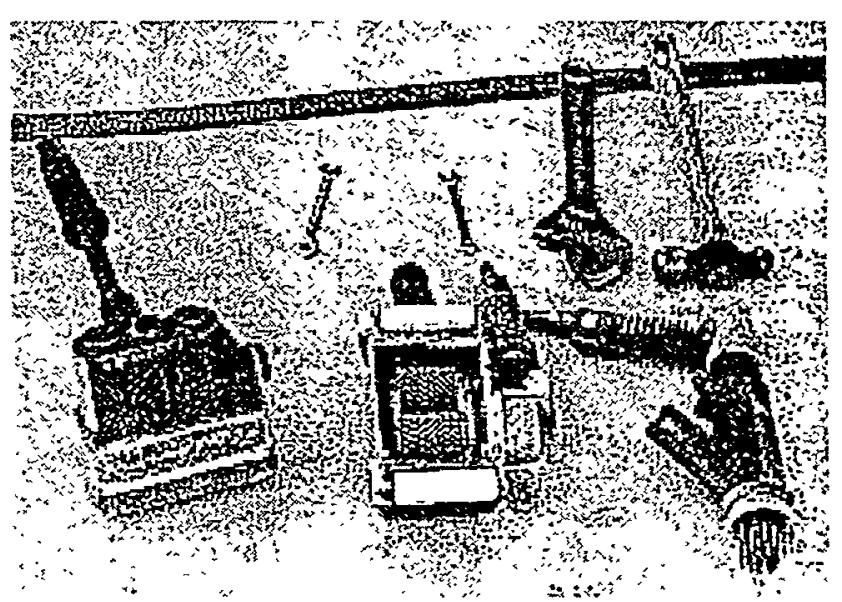

Figure 9. Attachments used with the LTC PTC-6. Shown from left to right: Scaler Hammer, Roto-Peen equipped with Starcutter metal wheels, and Needle Gun.

\subsection{COATING REMOVAL TECHNOLOGIES}

\subsubsection{Pegasus Coating Removal System (PCRS-7)}

PCRS-7 is a chemical coating removal method that has been developed by Pegasus International, Inc. for the removal of chemically resistant coatings (i.e., epoxies, urethanes, chlorinated coatings, rubber, elastomeric coatings, aluminum, vinyls, mastics, and most marine coatings). The PCRS-7 is an organic solvent mixture. It is light beige in color, slightly sweet in odor, and is supplied in 1-. 5-, or 55-gallon plastic buckets. Depending on the substrate and operating conditions, PCRS-7 is applied by pouring directly from the bucket or from a smaller container, and long- or short-handled spreaders or trowels are used to distribute it evenly across the surface. It can also be applied using a sprayer. Once distributed, the chemical is covered by a single layer of white freezer paper. Removal of the PCRS-7 and primary waste is achieved by lifting up and removing the paper, followed by scraping the surface using. trowels or large plastic shovels. Figure 10 shows the operating equipment used for spraying PCRS-7. An example of a coated surface following coating removal with PCRS-7 is shown in Figure 11. Appendix D details the MSDS for PCRS-7. 


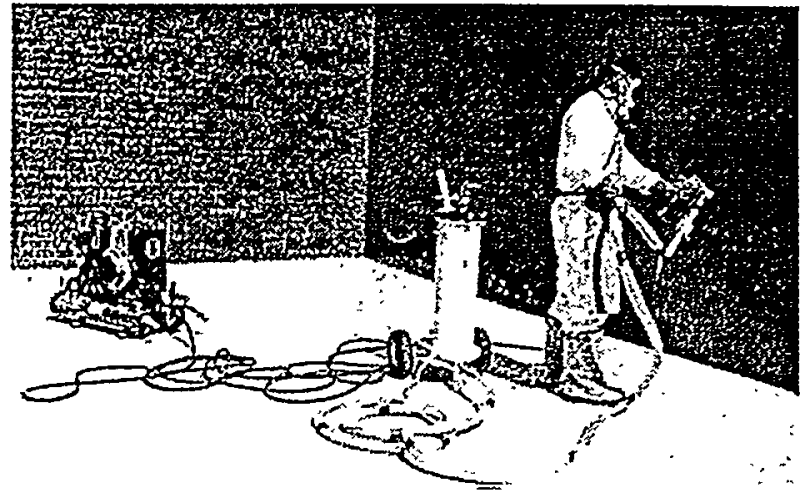

Figure 10. Operating equipment for PCRS-7 spray application. From left to right: air compressor, paint sprayer, and sprayer nozzle.

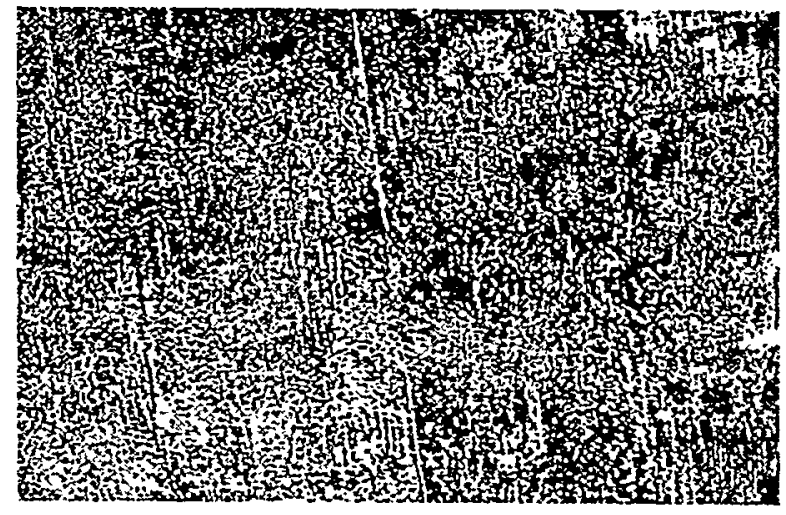

Figure 11. Coated ceiling following treatment with PCRS-7.

\subsubsection{Advance Recyclable Media System (ARMS ${ }^{\mathrm{Tx}}$ )}

The $\mathrm{ARMS}^{\text {tM }}$ equipment consists of the feed unit and the sifter unit. The feed unit is a portable, pneumatically powered device that propels the cleaning media against the surfaces to be decontaminated. The cleaning media is contained in the hopper mounted atop the unit. The media is fed to an auger device that mixes the cleaning media with compressed air. The sifter unit is a machine that mechanically removes large debris and powdery residues from the cleaning media after use. The unit vibrates causing the media to fall downward to a series of separation screens, which separate the debris from the media. The reusable media drastically reduces the waste generated per square foot of surface treated. Figures 12 and 13 show the ARMS ${ }^{\text {Tu }}$ feed unit and the sifter unit, respectively, at the demonstration. Appendix D details the MSDS for the ARMS ${ }^{\mathrm{TI}}$. 


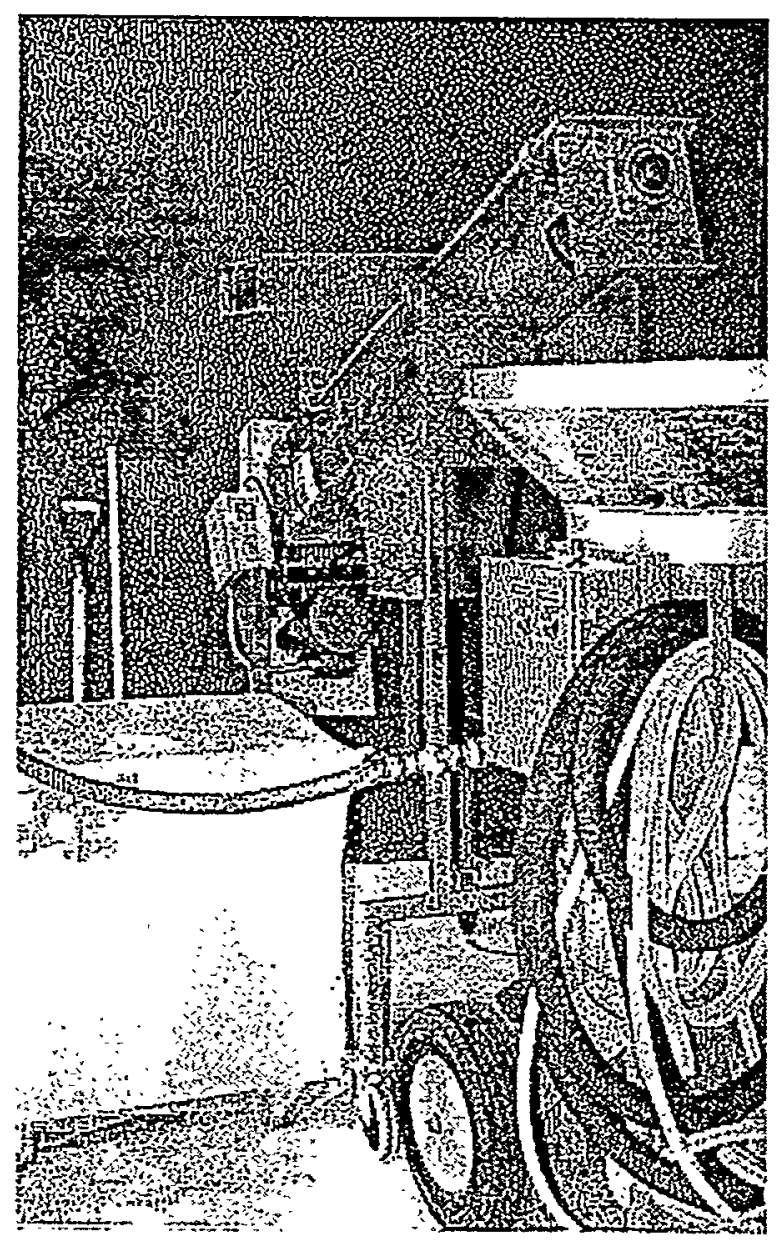

Figure 12. Front of ARMS ${ }^{2 \mathrm{~N}}$ feed unit.

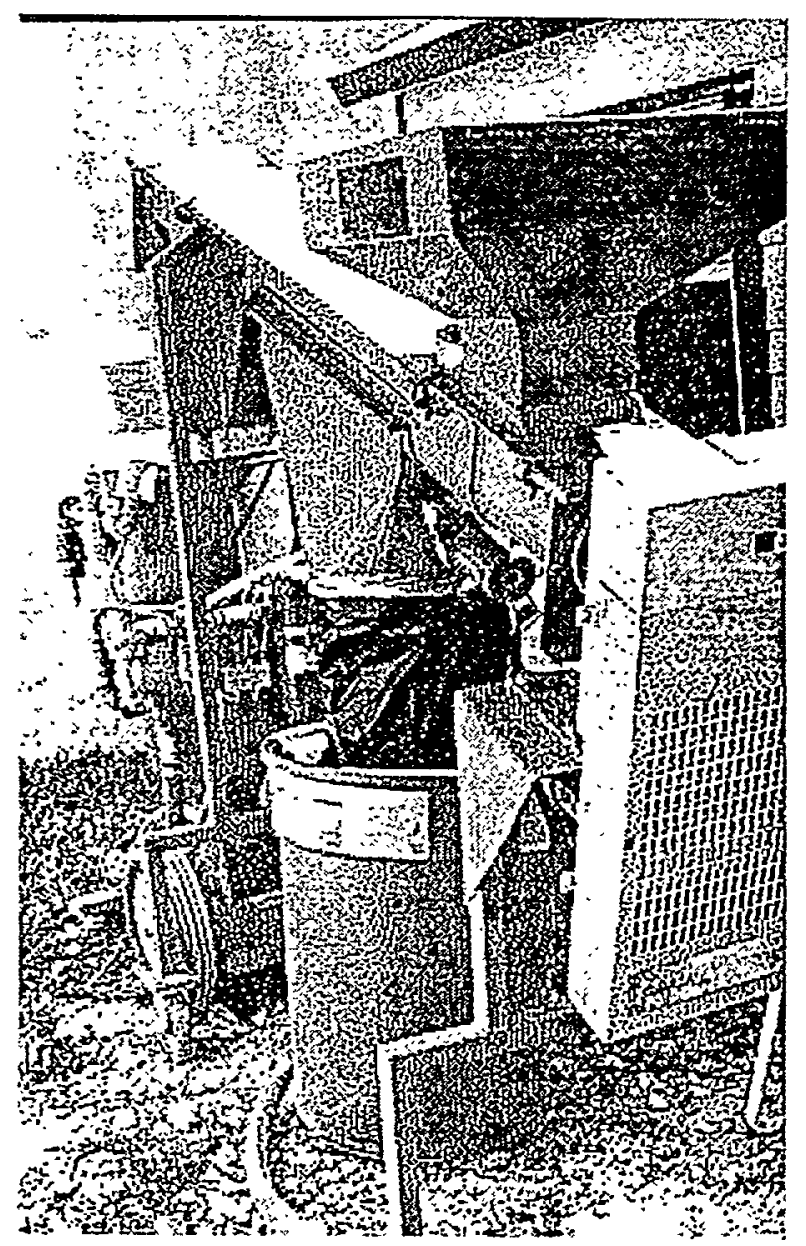

Figure 13. Operator blasting the coated concrete wall. 


\section{LESSONS LEARNED}

\subsection{DEVIATIONS FROM SCOPE OF WORK}

The goal of this study was to determine the relative suitability of selected decontamination technologies for deployment at the FEMP and MEMP remediation sites.

\subsubsection{Deviation from Site Specifications}

An additional coat of Ply-Mastic primer coating was applied to all of the coated concrete walls before applying the blue Ply-Thane 890 finish coating. The additional coat of Ply-Mastic primer was necessary because the first coat of primer did not completely seal the concrete wall. The application of the Ply-Mastic consisted of two 8-mils thick (wet) coats of Ply-Mastic primer which when dry, were approximately 14 mils thick.

\subsubsection{Technology Implementation Deviations}

\section{WallWalker ${ }^{\text {Th }}$}

The WallWalker ${ }^{\text {st }}$ robotic scabbler used two different support structures to hold it against the wall. A jib structure was used during the decontamination of the uncoated concrete wall and coated brick wall, while mounting brackets were used to support the WallWalker " ${ }^{\text {rs }}$ during the decontamination of the coated concrete wall. During the brick wall surface removal process, brittle fragments the bricks broke off and became wedged in the vacuum intake causing the WallWalker to bounce across the surface of the wall. Each time this occurred, operations had to be stopped to remove of the brick fragments before decontamination could continue. The snap ties in the concrete walls affected the operation of the WallWalker ${ }^{\text {Ts }}$ by breaking the low-friction vacuum seal surrounding the scabbling head. Each time the head passed over an area of wall containing a relatively superficial snap tie, the snap tie tore the foam seal, thereby causing a loss in the negative vacuum pressure of the system. The effect of the loss of negative vacuum pressure was twofold in that it resulted in a reduction in primary waste recovery, and decreased the adherence of the scabbler head to the wall surface. Once damaged, the low-friction vacuum seal of the scabbling head had to be completely replaced before operations could resume.

\section{LTC PTC-6}

LTC operators were instructed to operate the three tools (Scaler Hammer, Needle Gun, and RotoPeen equipped with Starcutter metal wheels) separately so as to permit concise, tool-specific data collection. Unfortunately, the LTC operators insisted on mixing the use of the tools, making the collection of separate performance data for each tool impossible. As a result, the data collected were based on the combined operation of the three tools. The entire decontamination procedure was not completed as planned, because LTC was not equipped to perform the procedure, and had not procured the necessary tools. 


\section{Advance Recyclable Media System (ARMS ${ }^{\text {Tis }}$ )}

Surface Technology System (STS) operators concluded ceiling decontamination operations leaving several patches of primer remaining on the ceiling's surface. STS operators noted the remaining primer but declined to continue working on the ceiling as they wished to keep within the self-imposed time restraints they had allotted for this demonstration.

\subsection{RECOMMENDATIONS FOR TECHNOLOGY ENHANCEMENT}

With the exception of the prototype WallWalker ${ }^{\mathrm{TM}}$ which is still in the developmental stage, all the other technologies tested during this project are fully developed and commercially available. All the technologies tested exhibited performance and operational limitations that would benefit from design improvements. The following recommendations are intended to address specific limitations identified during this project.

One general design improvement that would significantly enhance all three of the aggressive surface removal technologies assessed during this study would be the addition of an integrated removal depth and/or radioactivity sensor. The incorporation of an in situ sensor technology into these existing decontamination technologies would allow field operators to know precisely when the required removal depth or acceptable contaminant levels have been reached.

\subsubsection{WallWalker ${ }^{\text {tw }}$}

- The WallWalker" was unable to access areas (up to 24 inches in width) along the perimeter of the wall between the surface being treated and the adjacent walls, ceiling and floor. The inaccessible area (also referred to as the removal gap) left by this technology is relatively large when compared to other technologies, and could negatively impact this technology's standing when under consideration for certain jobs. Design improvements that would reduce the removal gap left by this technology are highly recommended.

- As the scabbler moved across the surface, the exposed snap ties ripped the low-friction vacuum seal surrounding the head. A redesign of the seal using more tear-resistant material(s) would minimize this problem and reduce the operational down-time required for maintenance. The redesign should also simplify the process of removing and replacing the seal by reducing the large number of screws on the seal mounting bracket. Another welcomed improvement would be pre-fabricated seals that do not need to be cut down to the appropriate size following installation.

- The WallWalker's ${ }^{\text {Tw }}$ scabbler head frequently lost contact with the wall. For the most part, this occurred when overlapping scabbling paths were used to achieve deeper surface removal. A consequence of overlapping is that the scabbler head travels across an uneven surface profile. Depending on the degree of scabbling path overlap and how uneven the resulting surface profile was, the scabbler head would lose its vacuum seal and consequently lose contact with the wall. It was observed that when the scabbling path was not overlapped, the scabbler head lost contact with the wall much less frequently. An operational recommendation to improve 
the performance of this technology would be to minimize the degree of overlap of the scabbling path during decontamination.

- Loss of contact also occurred when large chunks of brick were dislodged from the surface and became trapped between the scabbler head and the surface. This problem could be reduced by using a stronger vacuum, and increasing the size of the vacuum intake to facilitate the removal of larger chunks of debris.

- Whenever power to the control motors that lifted the scabbler head was interrupted, the head fell in a controlled (but unstoppable) fashion along its support cables. This could result in damage to the equipment and, in some circumstances, create a hazardous condition for workers. A braking mechanism that automatically engages when power is interrupted should be incorporated into the design.

\subsubsection{NELCO Porta Shot Blast ${ }^{\text {Tu }}$ Model JHJ-2000}

- The vacuum collection system used during the operation of this technology (Nilfisk GS625) was inadequate to prevent the loss of steel shot. Blast media lost in this way reduces its recyclability and increases the time and labor required to dispose of the secondary waste produced during technology operation. Furthermore, blast media lost in this manner introduces a potential projectile hazard for personnel in the immediate area, as well as facilitating the cross contamination of adjacent areas. A stronger vacuum system is recommended to improve blast media recovery.

- The blast head of this centrifugal shot blaster is equipped with a removable blast shield that is affixed with velcro. The function of the blast shield is to prevent the loss of the primary waste and steel shot by containing it for collection by the vacuum system. Problems were encountered when the blast shield became detached or tore during operations, resulting in the loss of shot. The use of a more resilient blast shield (possibly a brush blast shield) is strongly recommended.

\subsubsection{LTC PTC-6}

- The LTC PTC-6, using the Roto-Peen equipped with Starcutter metal wheels, the Scaler Hammer, and the Needle Gun, was capable of scabbling the entire wall surface. The handheld units required that the operators exert a great deal of pressure onto the surface of the wall and resulted in significant operator fatigue. In addition, the hand-held units produced strong vibrations that also contributed to the fatigue experienced by the operators. Ergonomic redesign of these hand-held units is strongly recommended to -reduce the strain placed on operators during decontamination and to ensure that cumulative worker health problems do not result from extended periods of operation.

- The Starcutter metal wheels used in the Roto-Peen hand-held unit were quickly and easily replaced; however, replacement was required every one to two hours because they wore out very quickly. A cost/benefits analysis of using Starcutter metal wheels made of more durable 
metals should be considered for future operations. For example, Starcutter metal wheels made of tungsten carbide are currently available, but they are substantially more expensive than the wheels used for this study.

\subsubsection{PCRS-7}

- The PCRS-7 organic solvent mixture did not completely remove the coating from the concrete wall and ceiling surfaces. Even though the complete application/removal process was performed twice on each surface, the PCRS-7 was unable to remove the coatings, and left a surface that had an intact (though apparently slightly abraded) blue epoxy coating. As is the case for all chemical coating removal systems, the degree of effectiveness of a particular coating remover is directly related to the coatings that are to be removed, and the properties of the surface the coating adheres to. The only way to unequivocally determine the effectiveness of a coating remover is to perform a test patch on the desired surface.

- The application of the PCRS-7 using spraying equipment was relatively easy and fast compared to hand application, but the PCRS-7 appeared to have corroded the interior surface of the plastic hoses used. Even though the hoses were flushed with water following the first application of PCRS-7, their structure was sufficiently degraded to rupture on the second use. A more chemically-resistant hose must be used with this system to prevent chemical spills and to reduce the amount of hose that would have to be placed in the secondary waste stream for a given remediation project.

- Long strips of freezer paper were placed on top of the applied PCRS-7 to reduce drying and thereby increase the activity time of the chemical on the surface coating. Unfortunately, after a few hours, the majority of the strips had fallen off of the wall and ceiling. A more effective method should be developed to reduce the drying of the chemical that would not introduce the chemical cross contamination risks and additional waste products inherent in this method.

\subsubsection{Advanced Recyclable Media System (ARMS ${ }^{\text {Dix }}$ )}

- The $A R M S^{\text {TII }}$ required an enclosed area to capture the media bouncing off of the cleaning surfaces and a ventilation system to recycle the air inside the enclosure. A large amount of thick dust was generated during operation, completely obscuring the view of the demonstration area. It was not clear whether the dust being generated was due to the soft consistency of the concrete or degradation of the media. Although the system has been tested on different concrete surfaces, minimal dust has been generated.

- Even when two $2000 \mathrm{cfm}$ HEPA filter vacuum units were used, the dust level still obscured the view. A more powerful vacuum system is recommended.

- A vapor generator was used to suppress the dust; however, because it did not appreciably reduce the dust generated during equipment operation, its use was discontinued. A more aggressive vapor generation system that employs water with the addition of detergents is 
recommended because this type of system has been shown in previous demolition studies to significantly reduce airborne particles.

- Collecting the media by shoveling it from the floor into the sifter unit should be improved. A large vacuum system capable of picking up the media and automatically dumping it into the sifter unit would eliminate the need for shoveling. 


\section{REFERENCES}

1. Fernald Environmental Restoration Management Corporation (FERMCO), 1995, Operable Unit 3 Remedial Design/Remedial Action Work Plan for Interim Remedial Action, Final, U.S. Department of Energy.

2. United States Department of Energy (DOE), 1994, Decommissioning Handbook, DOE/EM0142P, United States Department of Commerce, Springfield, VA.

3. United States Department of Energy (DOE), 1993, Oak Ridge National Technology Logic Diagram, ORNL/M2751, United States Department of Energy, Oak Ridge, TN.

4. United States Department of Energy (DOE), January 1994, Idaho National Engineering Laboratory Decontamination and Decommissioning Technology Logic Diagram, EGG- WTD11104, United States Department of Energy, Idaho Falls, Idaho.

5. Dickerson, K.S., August 1995, Contaminated Concrete: Occurrence and Emerging Technologies for DOE Decontamination, Final Report, Health Science Research Division, Oak Ridge National Laboratory, Oak Ridge, TN.

6. Remedial Action Program Information Center (RAPIC), Oak Ridge, TN.

7. Hemispheric Center for Environmental Technology Decontamination and Decommissioning Database, 1996, Hemispheric Center for Environmental Technology, Miami, FL.

8. Ebadian, M.A., November 1996, Analysis of Potential Concrete Floor Decontamination Technologies, Hemispheric Center for Environmental Technology (HCET), Florida International University, Miami, FL.

9. Ebadian, M.A. and Lagos, L.E., August 1995, Analysis of Potential Surface Blasting Decontamination Technologies for Structural Steel, Final Report, Hemispheric Center for Environmental Technology (HCET), Florida International University, Miami, FL. 


\section{APPENDIX A}

TECHNOLOGY DATA REQUIREMENTS: DEFINITIONS

$\cdot$ 


\section{TECHNOLOGY DATA REQUIREMENTS: DEFINITIONS}

The following is an explanation of the information presented in tabular form in Appendices B and $\mathrm{C}$. These tables present a summary of the technologies tested by this study. Appendix B presents aggressive surface removal technologies: WallWalker ${ }^{\mathrm{nt}}$, NELCO Porta Shot Blast ${ }^{\mathrm{Th}}$, and LTC PTC-6. Appendix C presents coating removal technologies: Advanced Recyclable Media System (ARMS ${ }^{\text {TiM }}$ ) and PCRS-7. The information is organized in Technology Overview tables, followed by Utility/Media Requirement tables, and Vendor Data tables. The text below describes each of these tables and their elements.

\section{TECHNOLOGY OVERVIEW TABLES}

The technologies shown in Tables B.1, B.2, B.3, C.1, and C.2 are described in terms of operating principles and equipment used. Technology class name, technology description, capital cost, benefits, limitations, production rate, labor classification, environmental conditions, characteristics of waste and support equipment are described in the technology overview tables.

\section{Technology Class}

Decontamination technologies have been categorized based on the physical principles employed during this operation. This classification system has been developed at FIU-HCET and is based on a system outlined in the Decommissioning Handbook[5].

\section{Technology Description}

The technology class description provides an introduction to the broad technology category. Details such as a description of the media are used, how the media are propelled, the vacuum system (if used), and the process by which the coating or contaminant is removed are provided.

\section{Estimated Capital Cost}

Capital cost represents the purchase cost of the technologies tested. These figures were obtained from the technology vendors as of September 1997.

\section{Benefits}

Benefits were obtained by performing a literature search of the individual technologies and conducting field demonstrations. If a conflict existed between published information and the field demonstrations, the data observed in the field testing were used. This section provides an overview of the potential benefits. 


\title{
Limitations
}

Limitations were obtained by performing a literature search of the individual technologies and conducting field demonstrations. If a conflict existed between published information and the field demonstrations, the data observed in the field testing were used. This section provides an overview of the potential limitations.

\section{Production Rate}

Site-Specific Production Rate $\left(\mathrm{ft}^{2} / \mathrm{hr}\right)$ : The total area of surface media removed divided by the total number of hours required to complete the task at a given site. Site-specific production time begins immediately following equipment mobilization and ends at job completion, just prior to equipment demobilization. Site-specific production time include breaks taken by operators, equipment adjustments and maintenance, surface media adjustments (for moveable surface media), handling of removed media, and consultations with test site administrators. Site-specific time does not include extended operator breaks (such as meals), test interruptions resulting from inclement weather, or the time required to correct major equipment failure.

\begin{abstract}
Absolute Production Rate ( $\left.\mathrm{ft}^{2} / \mathrm{hr}\right)$ : The total area of surface media removed divided by the total number of hours of equipment operation required to complete the task. Absolute production time includes only the time the equipment is in operation, and does not include time spent in sitespecific activities or maintenance.
\end{abstract}

The number of square feet of the concrete wall divided by the number of hours required to finish the entire $20 \times 10 \mathrm{ft}$. wall or ceiling is the absolute production rate. If a major equipment failure occurs, the time required to complete this major repair is not included in the calculation of the production rate. This production rate is expected to be higher than the site-specific production rate.

\section{Environmental Conditions}

A description of the work environment created by the operation of the technology is provided. These descriptions include presence or absence of visible emissions, water fog created in enclosure, visible air turbulence, and so forth.

\section{Characteristics of Waste}

This section describes the physical condition of the secondary waste as determined by visual observation. These observations include 1) fine powder with no observable difference from the media and the concrete or brick, and 2) small pieces of media mixed with concrete or brick.

\section{Support Equipment}

This section provides an overview of the major piece of equipment required to support the operation of the technology. 


\section{UTILITY/MEDIA REQUIREMENT TABLES}

Tables B.4 and C.3 describe the technology class, the technology name, the end point achieved, media type, media quantity, utility requirements, operation and maintenance requirements, and availability of equipment. Vendor information was also used and verified by field measurements.

\section{Technology Name}

The specific name of the technology as obtained from the vendor is provided.

\section{End Point Achieved}

The end point achieved by the technology is described under this category. The options for this category are coating removal, $<1 / 4$ inch removal, and $>1 / 4$ inch $<1 / 2$ inch removal or the actual maximum, minimum and average depth of removal measured.

\section{Media Type}

This section presents the general classification of the media used. Specific grades of media are recorded. The type of media varied with the required depth of removal and the required surface finish.

\section{Media Cost}

Vendor information was used to determine the cost of the media per pound. In the case of the technologies that use bits, the cost for a complete bit replacement was divided by the number of operating hours required before bit replacement. The bit replacement cost and the number of operating hours required before bit replacement were obtained from the vendor. Field observations of media replacement are also included.

\section{Media Quantity}

The quantity 'of media required per hour of operation was obtained from the vendor, and observation results are also included.

\section{Utility Requirements}

The types of utilities required to operate the technology are presented in this section. The utilities used during the field testing are shown. In many cases, optional power sources are available for each type of equipment. Utilities needed to operate the containment and ventilation system or any support equipment are shown in the tables. Also included is diesel fuel used by generator or compressor.

\section{Operating/Maintenance Requirements}

The operational/maintenance requirements provide an account of the types of operational and maintenance activities performed during the hours of operation. 


\section{Availability of Equipment}

The availability of equipment and supplies was obtained from the individual technology vendors. Long-lead procurement items are differentiated from equipment and supplies that are off-the-shelf items.

\section{Equipment Portability}

Equipment portability is broken down into four categories. These categories include equipment that can be moved by one person; equipment that requires two people to move; equipment that requires a forklift to move; or trailer-mounted equipment.

\section{VENDOR DATA TABLES}

Tables B.5 and C.4 provide a list of the vendors that participated in this study. The technology name, company name, address, phone and fax numbers, and type of services are provided.

\section{Technology Name}

Technology.

\section{Vendor Name}

Name of the company contracted to demonstrate the technology at FIU-HCET.

\section{Address, Phone and Fax numbers}

This section provides the address and phone and fax number of the company that performed the demonstration.

\section{Services}

This section details the type of services provided by the company. The three types of services are service provider, equipment provider, or service and equipment provider.

\section{HEALTH AND SAFETY ISSUES}

A separate report is available from the International Union of Operating Engineers related to the health and safety issues of the technologies. Please contact the IUOE at 304-253-8674 to obtain this report. 


\section{DATA REQUIREMENTS FOR WALLWALKER ${ }^{\mathrm{TM}}$, NELCO PORTA SHOT BLAST ${ }^{\mathrm{TM}}$ (JHJ-2000), AND LTC PTC-6}




\begin{tabular}{|c|c|c|c|c|}
\hline $\begin{array}{c}\text { Technology } \\
\text { Class }\end{array}$ & Technology Description & $\begin{array}{c}\text { Estimated } \\
\text { Capital Cost }\end{array}$ & Benefits & $\overline{\mathbf{L i}}$ \\
\hline $\begin{array}{l}\text { No model } \\
\text { number. } \\
\text { Prototype } \\
\text { innovative } \\
\text { technology }\end{array}$ & $\begin{array}{l}\text { The WallWalker }{ }^{\text {TM }} \text { robotic } \\
\text { scabbler consists of a motion } \\
\text { control system and a scabbler } \\
\text { head. The motion control system } \\
\text { controls the position, velocity, } \\
\text { and acceleration of the scabbler } \\
\text { head over a vertical surface. This } \\
\text { system works by independently } \\
\text { controlling the lengths of two } \\
\text { separate cables that may be } \\
\text { attached to the left and right sides } \\
\text { of the wall by mounting brackets } \\
\text { or, alternately, may be secured to } \\
\text { a free-standing jib structure. The } \\
\text { scabbler head uses a new low- } \\
\text { friction static seal that maintains } \\
\text { vacuum flow while maximizing } \\
\text { the vacuum pressure between the } \\
\text { scabbler head and the wall. The } \\
\text { scabbler head houses three } \\
\text { pistons, each mounted on an } \\
\text { independent suspension to allow } \\
\text { for surface height fluctuations } \\
\text { and to maintain optimum normal } \\
\text { force on the wall. The three } \\
\text { piston heads are designed to } \\
\text { rotate about a central axis } \\
\text { perpendicular to the wall as the } \\
\text { scabbler head travels across the } \\
\text { wall. The scabbler head has three } \\
\text { wheels that allow it to move } \\
\text { across the vertical surface. }\end{array}$ & $\begin{array}{l}\text { Motion Control } \\
\text { System (3475) } \\
\$ 150,000(1997) \\
\text { VAC-PAC 24A } \\
\$ 40,000(1997) \\
\text { Scabbler Head } \\
\$ 65,000(1997) \\
\text { Total: } \\
\$ 255,000(1997)\end{array}$ & $\begin{array}{l}\text { Remiote-operated } \\
\text { machinery reduces } \\
\text { strain on operators and } \\
\text { allows for greater safety } \\
\text { margins between } \\
\text { workers and potential } \\
\text { process hazards. } \\
\text { The scabbler head unit } \\
\text { can be reconfigured for } \\
\text { controlled steel abrasive } \\
\text { blasting, water blasting, } \\
\text { carbon dioxide pellet } \\
\text { blasting, and sodium } \\
\text { bicarbonate wet } \\
\text { blasting, as well as } \\
\text { power tool cleaning } \\
\text { operations. Can also be } \\
\text { used to apply coatings. } \\
\text { The motion control } \\
\text { system allows for a high } \\
\text { degree of precision and } \\
\text { repeatability across } \\
\text { surfaces. } \\
\text { Minimizes safety issues } \\
\text { associated with elevated } \\
\text { work areas. } \\
\text { Operations can be } \\
\text { conducted for long } \\
\text { hours. }\end{array}$ & $\begin{array}{l}\text { Deconta } \\
\text { coverag } \\
\text { inches c } \\
\text { edges, a } \\
\text { (This is } \\
\text { the supt } \\
\text { used). } \\
\text { When n } \\
\text { bracket! } \\
\text { the supi } \\
\text { the remc } \\
\text { between } \\
\text { wall wai } \\
\text { Gaps be } \\
\text { friction! } \\
\text { the surfa } \\
\text { the whe } \\
\text { head are } \\
\text { planes. } \\
\text { a possib } \\
\text { dust and } \\
\text { causes } t \\
\text { head to } \\
\text { from the } \\
\text { Cannot } \\
\text { rain. }\end{array}$ \\
\hline
\end{tabular}


Table B.1 anology Overview

\begin{tabular}{|c|c|c|c|c|c|}
\hline$\overline{\text { ations }}$ & Production Rate & $\begin{array}{c}\text { Labor } \\
\text { Classification }\end{array}$ & $\begin{array}{l}\text { Environmental } \\
\text { Conditions }\end{array}$ & Characteristics of Waste & $\begin{array}{c}\text { Support } \\
\text { Equipment }\end{array}$ \\
\hline $\begin{array}{l}\text { ation } \\
\text { within } 7 \\
\text { rners, } \\
\text { protrusions } \\
\text { sendent on } \\
\text { structure } \\
\text { nting } \\
\text { ere used for } \\
\text { t structure, } \\
\text { l gap } \\
\text { e ceiling and } \\
\text { bout } 2 \mathrm{ft} . \\
\\
\text { een the low- } \\
\text { tic seal and } \\
\text { occur when } \\
\text { of scabbler } \\
\text { t different } \\
\text { is allows for } \\
\text { release of } \\
\text { ebris, and } \\
\text { scabbler } \\
\text {;e contact } \\
\text { urface. } \\
\text { operated in }\end{array}$ & $\begin{array}{l}\text { Uncoated Concrete } \\
\text { Absolute: } 10.2 \mathrm{ft}^{2} / \mathrm{hr} \\
\text { Site Specific: } 8.56 \\
\mathrm{ft}^{2} / \mathrm{hr} \\
\text { Average removal } \\
\text { depth: } 0.3038 \text { inches } \\
\\
\text { Coated concrete } \\
\text { Absolute: } 8.17 \mathrm{ft}^{2} / \mathrm{hr} \\
\text { Site Specific: } 6.90 \\
\mathrm{ft}^{2} / \mathrm{hr} \\
\text { Average removal } \\
\text { depth: } 0.3810 \text { inches } \\
\\
\text { Coated brick: } \\
\text { Absolute: } 20 \mathrm{ft} / \mathrm{hr} \\
\text { Site Specific: } 15.18 \\
\mathrm{ft}^{2} / \mathrm{hr} \\
\text { Average removal } \\
\text { depth: } 0.1350 \text { inches }\end{array}$ & $\begin{array}{l}2 \text { Equipment } \\
\text { Operators }\end{array}$ & $\begin{array}{l}\text { No visible dust } \\
\text { No fumes } \\
\text { Sound } \\
\text { measurements of } 90 \\
\text { dB at } 10 \text { feet from } \\
\text { scabbler head } \\
\text { Sound } \\
\text { measurements of } \\
104 \text { dB at scabbler } \\
\text { head }\end{array}$ & $\begin{array}{l}\text { Uncoated concrete: } \\
\text { Concrete powder, fine and } \\
\text { gray. Resembles fine sand. } \\
\text { Waste Volume: } 0.0377 \\
\left(\mathrm{ft}^{3} / \mathrm{ft}^{2}\right) \\
\text { Coated concrete: } \\
\text { Concrete powder, fine and } \\
\text { gray. Resembles fine sand. } \\
\text { Waste Volume: } 0.0535 \\
\left(\mathrm{ft}^{3} / \mathrm{ft}^{2}\right) \\
\text { Coated Brick: } \\
\text { Brick powder; fine and red } \\
\text { with some blue and white } \\
\text { chips. } \\
\text { Waste Volume: } 0.0263 \\
\left(\mathrm{ft}^{3} / \mathrm{ft}^{2}\right)\end{array}$ & $\begin{array}{l}\text { Air Compressor } \\
\text { (LEROI) 375-cfm } \\
\text { \$21,749 (1997) } \\
\text { Rental for } \\
\text { compressor for one } \\
\text { week was: } \\
\text { \$ } 375 \text { (1997) }\end{array}$ \\
\hline
\end{tabular}




\begin{tabular}{|c|c|c|c|c|}
\hline $\begin{array}{c}\text { Technology } \\
\text { Class }\end{array}$ & Technology Description & $\begin{array}{c}\text { Estimated } \\
\text { Capital Cost }\end{array}$ & Benefits & Limitations \\
\hline $\begin{array}{l}\text { Technology } \\
\text { Name: } \\
\text { NELCO Porta } \\
\text { Shot Blast }{ }^{m}\end{array}$ & $\begin{array}{l}\text { Hand-held portable steel } \\
\text { shot blaster. This unit has a } \\
1 \text { inch by } 1.7 \text { inch blast } \\
\text { pattern and a } 1 / 2 \text { horsepower } \\
\text { electric/pneumatic motor. } \\
\text { The debris accumulates in } \\
\text { the dust collector and the } \\
\text { shot accumulates in the } \\
\text { hopper after rebounding } \\
\text { from the work surface. } \\
\text { Gravity then pulls the shot } \\
\text { into the impeller, where it is } \\
\text { recycled. Blaster holds } \\
\text { approximately } 2 \text { pounds of } \\
\text { shot. Horizontal, vertical, } \\
\text { and overhead hoppers are } \\
\text { included. This unit is also } \\
\text { equipped with a dual safety } \\
\text { shut-off valve. }\end{array}$ & $\begin{array}{l}\text { NELCO Porta } \\
\text { Shot Blast }{ }^{\mathrm{T}} \text { : } \\
\$ 3,000 \\
\text { Total: } \$ 3,000\end{array}$ & $\begin{array}{l}\text { Shot is continuously } \\
\text { recycled while the } \\
\text { shot feed spout is } \\
\text { open. } \\
\text { Machine can be } \\
\text { operated either } \\
\text { forward or } \\
\text { backward while } \\
\text { blasting. } \\
\text { Can be used on both } \\
\text { concrete and metal } \\
\text { surfaces. } \\
\text { Blast media is } \\
\text { relatively } \\
\text { inexpensive. } \\
\text { This unit can be } \\
\text { used in almost any } \\
\text { plane of operation } \\
\text { by using different } \\
\text { attachments. }\end{array}$ & $\begin{array}{l}\text { Not effective for } \\
\text { coating removal. } \\
\text { Not effective for } \\
\text { concrete removal } \\
\text { Not recommende } \\
\text { large surface are } \\
\text { A severe loss of s } \\
\text { results when the } \\
\text { seals lose contact } \\
\text { the surface }\end{array}$ \\
\hline
\end{tabular}




\section{Table B.2}

hnology Overview

\begin{tabular}{|c|c|c|c|c|}
\hline Production Rate & $\begin{array}{c}\text { Labor } \\
\text { Classification }\end{array}$ & $\begin{array}{c}\text { Environmental } \\
\text { Conditions } \\
\end{array}$ & $\begin{array}{c}\text { Characteristics of } \\
\text { Waste }\end{array}$ & Support Equipment \\
\hline $\begin{array}{l}\text { Un-Coated Concrete: } \\
\text { Absolute: } 19.36 \mathrm{ft}^{2} / \mathrm{hr} \\
\text { Site Specific: } 15.19 \mathrm{ft}^{2} / \mathrm{hr} \\
\text { Average removal depth: } \\
0.0377 \text { in. } \\
\\
\text { Coated Concrete: } \\
\text { Absolute: } 8.67 \mathrm{ft} / \mathrm{hr} \\
\text { Site Specific: } 6.71 \mathrm{ft} / \mathrm{hr} \\
\text { Average removal depth: } \\
0.0344 \text { in. } \\
\text { Coated Brick: } \\
\text { Absolute: } 17.20 \mathrm{ft}^{2} / \mathrm{hr} \\
\text { Site Specific: } 12.44 \mathrm{ft}^{2} / \mathrm{hr} \\
\text { Average removal depth: } \\
0.0715 \text { in. }\end{array}$ & $\begin{array}{l}1 \text { Equipment } \\
\text { Operator }\end{array}$ & $\begin{array}{l}\text { No fumes. } \\
\text { Visible dust. } \\
\text { Sound measurements of } \\
79 \mathrm{~dB} \text { at } 25 \mathrm{ft} . \\
\text { Sound measurements of } \\
95 \mathrm{~dB} \text { next to } \\
\text { operator. } \\
\text { Projectile hazards from } \\
\text { flying steel shots. }\end{array}$ & $\begin{array}{l}\text { Uncoated concrete: } \\
\text { Fine, gray, concrete } \\
\text { powder. Resembles } \\
\text { fine sand. } \\
\text { Waste Volume: N/A } \\
\\
\text { Coated concrete: } \\
\text { Fine, gray, concrete } \\
\text { powder with blue and } \\
\text { white chips. } \\
\text { Waste Volume: N/A } \\
\text { Coated Brick: } \\
\text { Fine, brown, brick } \\
\text { powder with blue and } \\
\text { white chips. } \\
\text { Waste Volume:N/A }\end{array}$ & $\begin{array}{l}\text { Vacuum Cleaner: } \\
\text { NilfiskGS625 } \$ 4,000 \\
\text { Floor Magnet: } \$ 500\end{array}$ \\
\hline
\end{tabular}


Techno]

\begin{tabular}{|c|c|c|c|c|}
\hline $\begin{array}{c}\text { Technology } \\
\text { Class } \\
\end{array}$ & Technology Description & $\begin{array}{c}\text { Estimated } \\
\text { Capital Cost }\end{array}$ & Benefits & $\overline{\text { Limitations }}$ \\
\hline $\begin{array}{l} \\
\text { Technology } \\
\text { Name: } \\
\text { LTC Power } \\
\text { Tool Center } \\
\\
\text { Model } \\
\text { Number: } \\
\text { LTC PTC-6 }\end{array}$ & $\begin{array}{l}\text { The LTC Needle-Gun is a hand- } \\
\text { held needle scaler that operates } \\
\text { within an evacuated enclosure } \\
\text { called a shroud, which prevents } \\
\text { the release of dust, debris, and } \\
\text { airborne contaminants into the } \\
\text { environment. The delivery } \\
\text { system for the scaler consists of } \\
\text { thin metal needles that rotate } \\
\text { 360 degrees with a back and } \\
\text { forth motion to scabble the } \\
\text { desired surface media. } \\
\text { The LTC Roto Peen scaler is a } \\
\text { hand-held unit that operates } \\
\text { within an evacuated enclosure } \\
\text { called a shroud; which prevents } \\
\text { the release of dust, debris, and } \\
\text { airborne contaminants into the } \\
\text { environment. The delivery } \\
\text { system for the scaler consists of } \\
\text { starcutter wheels that scabble } \\
\text { the desired surface media. } \\
\text { The LTC shrouded scaler } \\
\text { hammer is a hand-held unit that } \\
\text { operates within an evacuated } \\
\text { enclosure called a shroud, which } \\
\text { prevents the release of dust, } \\
\text { debris, and airborne } \\
\text { contaminants into the } \\
\text { environment. The delivery } \\
\text { system for the scaler consists of } \\
\text { heavy duty pistons that move in } \\
\text { a back and forth motion to chip } \\
\text { away at the desired surface } \\
\text { media. }\end{array}$ & $\begin{array}{l}\text { Starcutter: } \\
\text { \$1,495 (1996) } \\
\text { Needle Gun: } \\
\$ 995 \text { (1996) } \\
\text { Scaler Hammer: } \\
\text { \$1210 (1997) } \\
\quad . \\
\text { LTC PTC-6: } \\
\text { \$17,706 (1996) } \\
\text { Total: } \\
\$ 21,406\end{array}$ & $\begin{array}{l}\text { Combination of } \\
\text { tools allows } \\
\text { technology to cover } \\
100 \% \text { of the wall } \\
\text { surface. } \\
\text { Up to } 6 \text { operators } \\
\text { can work at the } \\
\text { same time. }\end{array}$ & $\begin{array}{l}\text { Can not be used } \\
\text { under wet conditi } \\
\text { or on wet surface } \\
\text { Not field verified } \\
\text { Not effective for } \\
\text { aggiessive remor } \\
\text { of concrete or br } \\
\text { surface greater tt } \\
1 / 8 \text { inch thick. }\end{array}$ \\
\hline
\end{tabular}




\section{e B.3}

\section{y Overview}

\begin{tabular}{|c|c|c|c|c|}
\hline Production Rate & $\begin{array}{c}\text { Labor } \\
\text { Classification }\end{array}$ & $\begin{array}{c}\text { Environmental } \\
\text { Conditions }\end{array}$ & $\begin{array}{l}\text { Characteristics of } \\
\text { Waste }\end{array}$ & $\begin{array}{c}\text { Support } \\
\text { Equipment }\end{array}$ \\
\hline $\begin{array}{l}\text { Uncoated concrete } \\
\text { Absolute: } 11.87 \mathrm{ft}^{2} / \mathrm{hr} \\
\text { Site Specific: estimated } 6.9 \mathrm{ft}^{2} / \mathrm{hr} \\
\text { Average removal depth: } 0.0786 \\
\text { inches } \\
\text { Coated concrete } \\
\text { Absolute: } 9.18 \mathrm{ft}^{2} / \mathrm{hr} \\
\text { Site Specific: estimated } 5.12 \mathrm{ft} / \mathrm{hr} \\
\text { Average removal depth: } 0.0679 \\
\text { inches } \\
\text { Coated brick } \\
\text { Absolute: } 8.69 \mathrm{ft}^{2} / \mathrm{hr} \\
\text { Site Specific: estimated } 5.69 \mathrm{ft}^{2} / \mathrm{hr} \\
\text { Average removal depth: } 0.057 \\
\text { inches } \\
\text { Note: All values noted are in } 2 \\
\text { man hours. } \\
\text { Coated concrete wall: } \\
\text { NG: } 163 \text { minutes, ST: } 509 \\
\text { minutes, HM: } 118 \text { minutes } \\
\text { Coated brick wall: } \\
\text { NG: } 154 \text { minutes, ST: } 448 \\
\text { minutes, HM: } 23 \text { minutes } \\
\text { Un-coated concrete wall: } \\
\text { NG: } 83 \text { minutes, ST: } 402 \text { minutes, } \\
\text { HM: } 323 \text { minutes } \\
\text { NG: Needle Gun } \\
\text { ST: Roto-Peen equipped with } \\
\text { Starcutter metal wheels } \\
\text { HM: Scalar Hammer }\end{array}$ & $\begin{array}{l}1 \text { Equipment } \\
\text { Operator }\end{array}$ & $\begin{array}{l}\text { No fummes } \\
\vdots \\
\text { Visible dust } \\
\text { Sound measurements } \\
\text { of } 120 \mathrm{~dB} \text { at } 20 \mathrm{feet} \\
\text { from operator. } \\
\text { High reading of } 120 \\
\mathrm{~dB} \\
\text { Low reading of } 98 \mathrm{~dB}\end{array}$ & $\begin{array}{l}\text { Uncoated concrete: } \\
\text { Fine, gray concrete } \\
\text { powder. Resembles } \\
\text { fine sand. } \\
\text { Waste Volume: } \\
0.0127\left(\mathrm{ft}^{3} / \mathrm{ft}^{2}\right) \\
\\
\text { Coated concrete: } \\
\text { Fine, gray concrete } \\
\text { powder with small } \\
\text { blue and white } \\
\text { chips. Resembles } \\
\text { fine sand. } \\
\text { Waste Volume: } \\
0.0127\left(\mathrm{ft}^{3} / \mathrm{ft}^{2}\right) \\
\\
\text { Coated Brick: } \\
\text { Fine, brown brick } \\
\text { powder with } \\
\text { chunks of white } \\
\text { and blue chips. } \\
\text { Waste Volume: } \\
0.0126\left(\mathrm{ft}^{3} / \mathrm{ft}^{2}\right)\end{array}$ & $\begin{array}{l}\text { Air } \\
\text { compressor } \\
\text { (Ingersollrand } \\
250 \mathrm{cfm} \text { rented } \\
\text { from } \\
\text { Blanchard } \\
\text { Machinery). } \\
\\
\text { Air dryer: no } \\
\text { information } \\
\text { available from } \\
\text { vendor }\end{array}$ \\
\hline
\end{tabular}


Utility/Mi

\begin{tabular}{|c|c|c|c|c|}
\hline $\begin{array}{c}\text { Technology } \\
\text { Class }\end{array}$ & $\begin{array}{c}\text { Technology } \\
\text { Name }\end{array}$ & End Point Achieved & Media Type & Media Cost \\
\hline $\begin{array}{l}\text { Robotic } \\
\text { Scarification }\end{array}$ & $\begin{array}{c}\text { WallWalker }^{\mathrm{TM}} \\
\cdot\end{array}$ & $\begin{array}{l}\text { Average depth of } \\
\text { removal on walls } \\
\text { (inches) } \\
\text { uncoated concrete: } \\
0.3038 \\
\text { coated concrete: } 0.3810 \\
\text { coated brick } 0.1350\end{array}$ & Tungsten bits & $\begin{array}{l}\$ 300.00 / \text { set of } \\
\text { scabbling bits and } \\
\text { spiral pins }\end{array}$ \\
\hline $\begin{array}{l}\text { Steel } \\
\text { Abrasive } \\
\text { Blasting }\end{array}$ & $\begin{array}{l}\text { NELCO Porta } \\
\text { Shot Blast } \\
\text { Model \# JHJ-2000 }\end{array}$ & $\begin{array}{l}\text { uncoated concrete: } \\
0.0377 \\
\text { coated concrete: } 0.0344 \\
\text { coated brick: } 0.0715\end{array}$ & Steel shot (\#390) & $\$ 0.40$ per pound \\
\hline Scarification & $\begin{array}{l}\text { LTC Power Tool } \\
\text { Center } \\
\text { Scaler Hammer } \\
\text { Needle Gun } \\
\text { Roto-Peen } \\
\text { equipped with } \\
\text { Starcutter metal } \\
\text { wheels }\end{array}$ & $\begin{array}{l}\text { uncoated concrete: } \\
0.0786 \\
\text { coated concrete: } 0.0679 \\
\text { coated brick: } 0.0570\end{array}$ & $\begin{array}{l}\text { Scaler Hammer: } \\
\text { tungsten carbide } \\
\text { Needle Gun: 3-mm } \\
\text { flat tip beryllium } \\
\text { copper spark } \\
\text { Roto-Peen: } \\
\text { Starcutter metal } \\
\text { wheels }\end{array}$ & $\begin{array}{l}\$ 147.00 / \text { set of three } \\
(1996) \\
\$ 21.00 / \text { needle set } \\
(1996) \\
\$ 225.00 / \text { Assembly } \\
(1996)\end{array}$ \\
\hline \multicolumn{5}{|c|}{ * Based on absolute time } \\
\hline
\end{tabular}


ble B.4

\section{ia Requirements}

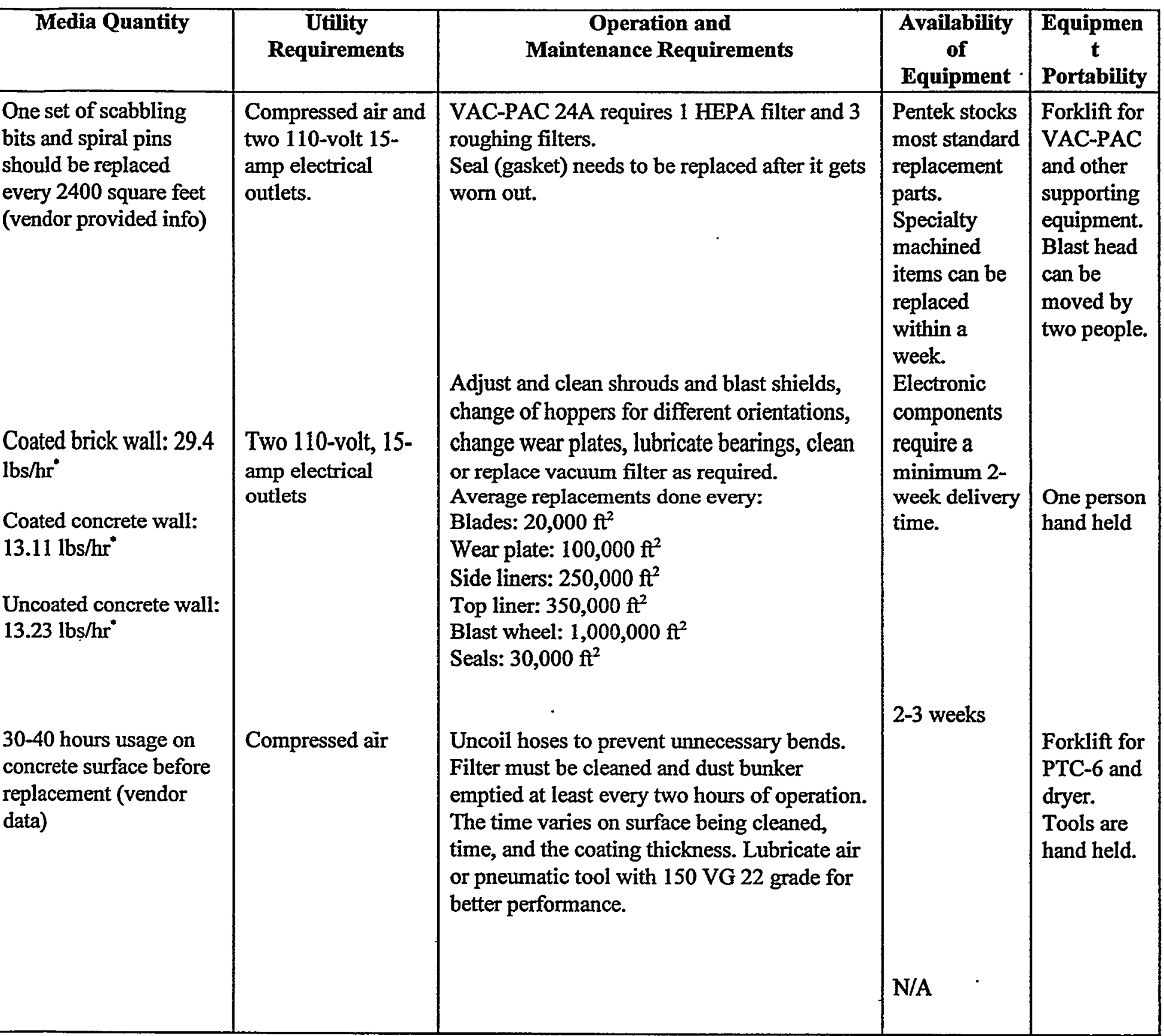


Table B.5

Vendor Data

\begin{tabular}{|c|c|c|c|}
\hline Technology Name & $\begin{array}{l}\text { NELCO PORTA SHOT } \\
\text { BLAST }^{\pi *}(\mathrm{JHJ}-2000)\end{array}$ & WALLWALKER ${ }^{\text {TM }}$ & LTC PTC-6 \\
\hline Vendor Name & Pegasus International, Inc. & Pentek, Inc. & LTC Americas, Inc. \\
\hline Vendor Address & $\begin{array}{l}106 \text { Railroad Street } \\
\text { Schenley, PA } 15682\end{array}$ & $\begin{array}{l}1026 \text { Fourth Avenue } \\
\text { Coraopolis, } \\
\text { PA 15108-1659 }\end{array}$ & $\begin{array}{l}22446 \text { Davis Drive, } \\
\text { Suite } 142 \\
\text { Sterling, VA } 20164\end{array}$ \\
\hline Phone Number & (412) $845-2838$ & (412) $262-0725$ & $\begin{array}{l}(800) .822-2332 \\
(703) 406-3005\end{array}$ \\
\hline Fax Number & (412) $845-1794$ & (412) 262-0731 & (703) $406-4523$ \\
\hline Services & $\begin{array}{l}\text { Equipment and service } \\
\text { provider }\end{array}$ & $\begin{array}{l}\text { Equipment and service } \\
\text { provider }\end{array}$ & $\begin{array}{l}\text { Equipment and service } \\
\text { provider }\end{array}$ \\
\hline
\end{tabular}




\section{APPENDIX C}

\section{DATA REQUIREMENTS}

FOR PCRS-7 AND ADVANCED MEDIA RECYCLING SYSTEM (ARMS ${ }^{\text {Tiy }}$ ) 


\begin{tabular}{|c|c|c|c|c|}
\hline $\begin{array}{l}\text { Technology } \\
\text { Class }\end{array}$ & Technology Description & $\begin{array}{c}\text { Estimated } \\
\text { Capital Cost }\end{array}$ & Benefits & \\
\hline $\begin{array}{l}\text { Technology } \\
\text { Name: } \\
\text { Pegasus Chemical } \\
\text { Coating Removal } \\
\text { System (PCRS) } \\
\\
\\
\text { Model Number: } \\
\text { PCRS-7 }\end{array}$ & $\begin{array}{l}\text { PCRS-7 is a chemical coating } \\
\text { removal method that has been } \\
\text { developed by Pegasus International, } \\
\text { Inc. for the removal of chemically } \\
\text { resistant coatings (i.e. epoxies, } \\
\text { urethanes, chlorinated coatings, } \\
\text { rubber, elastomeric coatings, } \\
\text { aluminum, vinyls, mastics, and most } \\
\text { marine coatings). The PCRS-7 is an } \\
\text { organic solvent mixture, light beige } \\
\text { in color, slightly sweet in odor, and } \\
\text { supplied in 1-, 5-, or } 55 \text {-gallon } \\
\text { plastic buckets. Depending on the } \\
\text { substrate and operating conditions, } \\
\text { PCRS-7 is applied by pouring } \\
\text { directly from the bucket or from a } \\
\text { smaller container, and long- and/or } \\
\text { short-handled spreaders or trowels } \\
\text { are used to distribute it evenly } \\
\text { across the surface. It can also be } \\
\text { applied by using a sprayer to spray } \\
\text { the coating on to the surface. Once } \\
\text { distributed, the chemical is covered } \\
\text { by a single layer of white freezer } \\
\text { paper. Removal of the PCRS-7 and } \\
\text { primary waste is achieved by lifting } \\
\text { up and removing the paper, } \\
\text { followed by scraping the surface } \\
\text { using trowels and/or large plastic } \\
\text { shovels. }\end{array}$ & $\begin{array}{l}\text { Service prices range } \\
\text { from } \$ 48 \text { to } \$ 100 \text { per } \\
\text { gallon (1997). Data } \\
\text { provided by vendor. } \\
\text { Total of } 40 \text { gallons } \\
\text { used for the coated } \\
\text { concrete wall and } \\
\text { concrete ceiling. ' } \\
\text { Applied twice. } \\
\text { Approximate area } \\
\text { covered: } \\
\text { Wall: } 200 \mathrm{ft}^{2} \\
\text { Ceiling: } 200 \mathrm{ft}^{2}\end{array}$ & $\begin{array}{l}\text { High viscosity } \\
\text { allows it to remove } \\
\text { coatings from non- } \\
\text { horizontal surface } \\
\text { geometries. }\end{array}$ & $\begin{array}{l}\text { Ret } \\
\text { is } \mathrm{r} \\
\text { con } \\
\text { for } \\
\text { eva } \\
\text { con } \\
\text { a la } \\
\text { clot } \\
\text { paf } \\
\text { cov } \\
\text { the } \\
\text { to } \\
\text { eva } \\
\text { Fre } \\
\text { not }\end{array}$ \\
\hline
\end{tabular}




\section{$\mathbf{T}$}

\begin{tabular}{|c|c|c|c|c|}
\hline $\begin{array}{l}\text { Technology } \\
\text { Class } \ldots \\
\end{array}$ & Technology Description & $\begin{array}{c}\text { Estimated } \\
\text { Capital Cost }\end{array}$ & Benefits & Limitation \\
\hline $\begin{array}{l}\text { Sponge Blasting } \\
\text { Technology Name: } \\
\text { Advanced Recyclable } \\
\text { Media System } \\
\left(\text { ARMS }^{\text {x }}\right)\end{array}$ & $\begin{array}{l}\text { The ARMS equipment } \\
\text { consists of the feed unit } \\
\text { and the sifter unit. The } \\
\text { Feed Unit is a portable } \\
\text { pneumatically powered } \\
\text { device that propels the } \\
\text { cleaning media against the } \\
\text { surfaces to be } \\
\text { decontaminated. The } \\
\text { cleaning media is contained } \\
\text { in the hopper mounted atop } \\
\text { the unit. The media is fed } \\
\text { to an auger device which } \\
\text { mixes the cleaning media } \\
\text { with compressed air. The } \\
\text { sifter unit is a machine that } \\
\text { is used to mechanically } \\
\text { remove large debris and } \\
\text { powdery residues from the } \\
\text { cleaning media after use. } \\
\text { The unit vibrates causing } \\
\text { the media to fall downward } \\
\text { to a series of separation } \\
\text { screens, which separate the } \\
\text { debris from the media. The } \\
\text { reusable media drastically } \\
\text { reduces the waste } \\
\text { generated per square foot } \\
\text { of surface treated. }\end{array}$ & $\begin{array}{l}\text { Arms Feed Unit: } \\
\$ 10,800.00 \\
\text { Arms Sifter: } \\
\$ 7,200.00 \\
\text { Arms Vapor } \\
\text { Generator: } \\
\$ 5,400.00 \\
\text { Total: } \\
\$ 23,400\end{array}$ & $\begin{array}{l}\text { Recyclable media } \\
\text { Environmentally } \\
\text { friendly } \\
\text { Lower volume of } \\
\text { waste }\end{array}$ & $\begin{array}{l}\text { Containment an } \\
\text { ventilation requi } \\
\text { for air exchange } \\
\text { Media is recycl } \\
\text { shoveling by ha }\end{array}$ \\
\hline
\end{tabular}




\section{Table C.2}

nology Overview

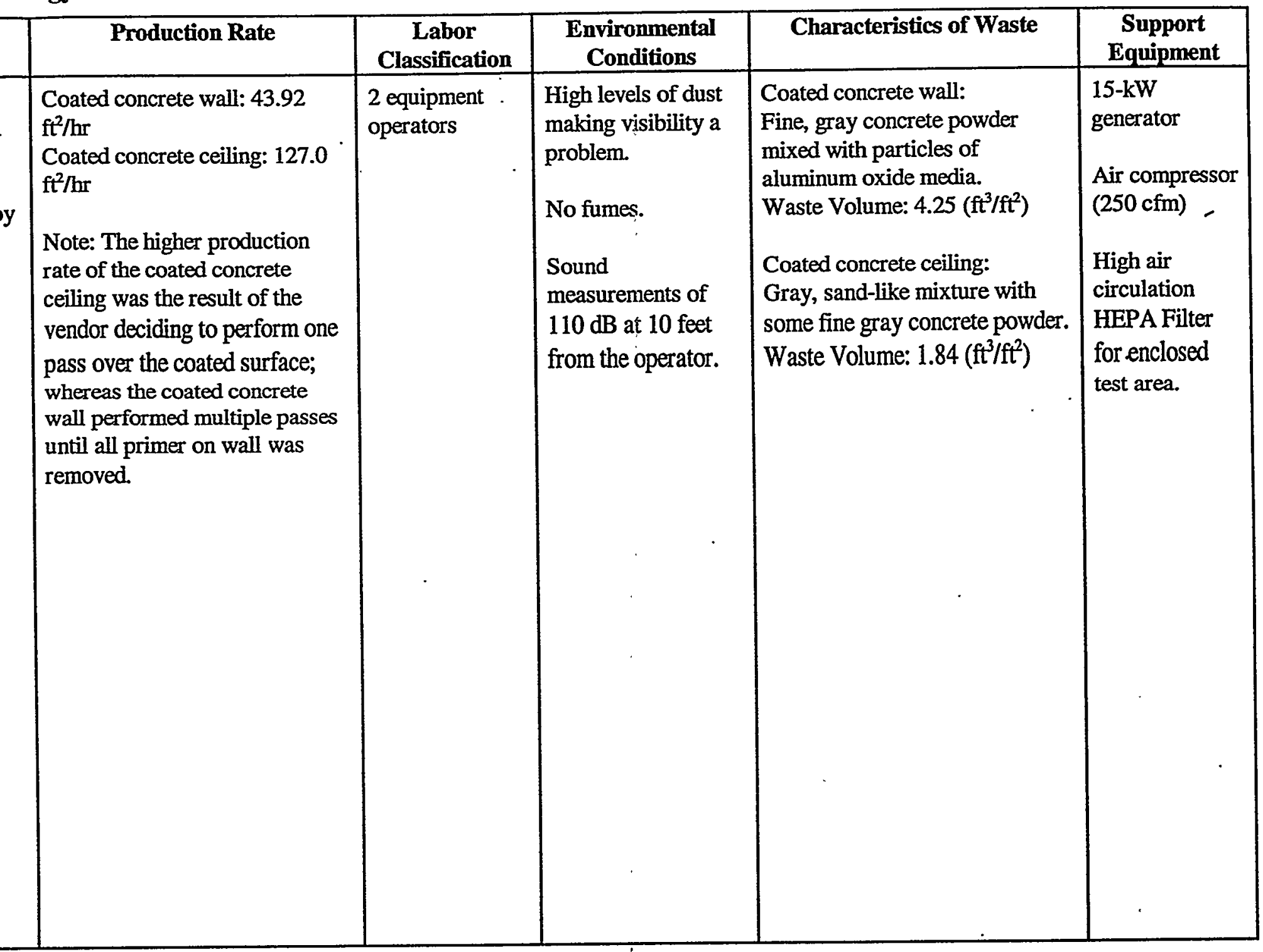


$\mathbf{T}$

Utility/Me

\begin{tabular}{|l|l|l|l|l}
\hline $\begin{array}{l}\text { Technology } \\
\text { Class }\end{array}$ & Technology Name & End Point Achieved & Media Type & Media Cost \\
\hline $\begin{array}{l}\text { Coating } \\
\text { remover }\end{array}$ & $\begin{array}{l}\text { Pegasus Chemical } \\
\text { Coating Removal } \\
\text { System } \\
\text { PCRS-7 }\end{array}$ & Coating removal & $\begin{array}{l}\text { Chemical coating } \\
\text { PCRS-7 }\end{array}$ & $\begin{array}{l}\text { \$125 per 5 gallon } \\
\text { bucket (1997) } \\
\text { (vendor data) }\end{array}$ \\
$\begin{array}{l}\text { Sponge } \\
\text { blasting }\end{array}$ & $\begin{array}{l}\text { Media System } \\
\text { (ARMS }\end{array}$ & Coating removal & $\begin{array}{l}\text { Aluminum oxide } \\
\text { fiber }\end{array}$ & $\begin{array}{l}\$ 70-\$ 90 / 50 \mathrm{lb} \text { bag } \\
\text { (vendor data) }\end{array}$ \\
\hline
\end{tabular}




\section{e C.3}

\section{Requirements}

\begin{tabular}{|c|c|c|c|c|}
\hline Media Quantity & $\begin{array}{c}\text { Utility } \\
\text { Requirements }\end{array}$ & $\begin{array}{l}\text { Operation and } \\
\text { Maintenance } \\
\text { Requirements }\end{array}$ & $\begin{array}{c}\text { Availability of } \\
\text { Equipment }\end{array}$ & $\begin{array}{l}\text { Equipment } \\
\text { Portability }\end{array}$ \\
\hline $\begin{array}{l}10 \text { gallons used for first } \\
\text { and } 10 \text { gallons used for } \\
\text { second application on } \\
\text { the coated concrete } \\
\text { wall. } \\
10 \text { gallons used for first } \\
\text { and } 10 \text { gallons used for } \\
\text { second application on } \\
\text { the coated concrete } \\
\text { ceiling. } \\
\text { Total : } 40 \text { gallons used }\end{array}$ & $\begin{array}{l}\text { Compressed air } \\
\text { (35 psi) for sprayer }\end{array}$ & $\begin{array}{l}\text { Clean-up of rollers, } \\
\text { brushes and sprayers. } \\
\text { Workers should avoid } \\
\text { skin contact and } \\
\text { inhalation of vapors. Any } \\
\text { possible ignition source } \\
\text { should be removed as the } \\
\text { vapors form an explosive } \\
\text { mixture with air. PCRS-7 } \\
\text { should be stored in a } \\
\text { cool, well-ventilated area } \\
\text { away from oxidizers. }\end{array}$ & 2-3 weeks & One person \\
\hline $\begin{array}{l}15 \mathrm{ft}^{3} / \mathrm{hr} \\
\text { (vendor supplied } \\
\text { information) }\end{array}$ & $\begin{array}{l}\text { Compressed air } \\
\text { and } 110 \text { volts } 15 \\
\text { amps }\end{array}$ & $\begin{array}{l}\text { ARMS }^{\mathrm{TM}} \text { unit needs } \\
\text { motor oil } \\
\text { Grease Sifter shaft. }\end{array}$ & $\begin{array}{l}\text { ARMS } S^{\text {nx }} 8 \text { weeks } \\
\text { Media: } 2 \text { weeks }\end{array}$ & One person \\
\hline
\end{tabular}


Table C.4

Vendor Data

\begin{tabular}{|l|c|c|}
\hline Technology Name & PCRS-7 & $\begin{array}{c}\text { ADVANCED RECYCLABLE } \\
\text { MEDIA SYSTEM (ARMS }\end{array}$ \\
\hline Vendor Name & Pegasus International, Inc. & Surface Technology System \\
\hline Vendor Address & 106 Railroad Street & $\begin{array}{c}75 \text { East Market St. } \\
\text { Akron OH, } 44308\end{array}$ \\
\hline Schenley, PA 15682 & $\begin{array}{c}497-5905 \\
\text { Phone Number }\end{array}$ & $(330) 376-2700$ \\
\hline Fax Number & (412) $845-2838$ & (330) $374-0101$ \\
\hline Services & (412) $845-1794$ & Equipment and service provider \\
\hline
\end{tabular}




\section{MATERIAL SAFETY DATA SHEETS FOR PCRS-7 AND ARMS ${ }^{\text {TM }}$ ALUMINUM OXIDE FIBER MEDIA (TYPE B)}


FRODUCT:

P.C.R.S. 7

HGDS DATE OF DREPARATION/REYIBION: APRIL 15, 2996

MANOFACTURrR: Pegasus International, Inc. 105 Rallroad street Schenley, PA 15682, USA

garSB HAZAND RATINGB

Health 2

Plaumability 1

Reactivity 0

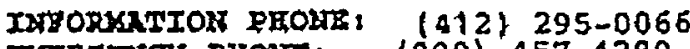

Personal Protection $\mathrm{C}$

IRERGEACY PHOAT: (800) 457-4280

$0=$ Least; $1=81$ ight

2 -Moderate; $3 \mathrm{mH}$ igh

4 Extreme

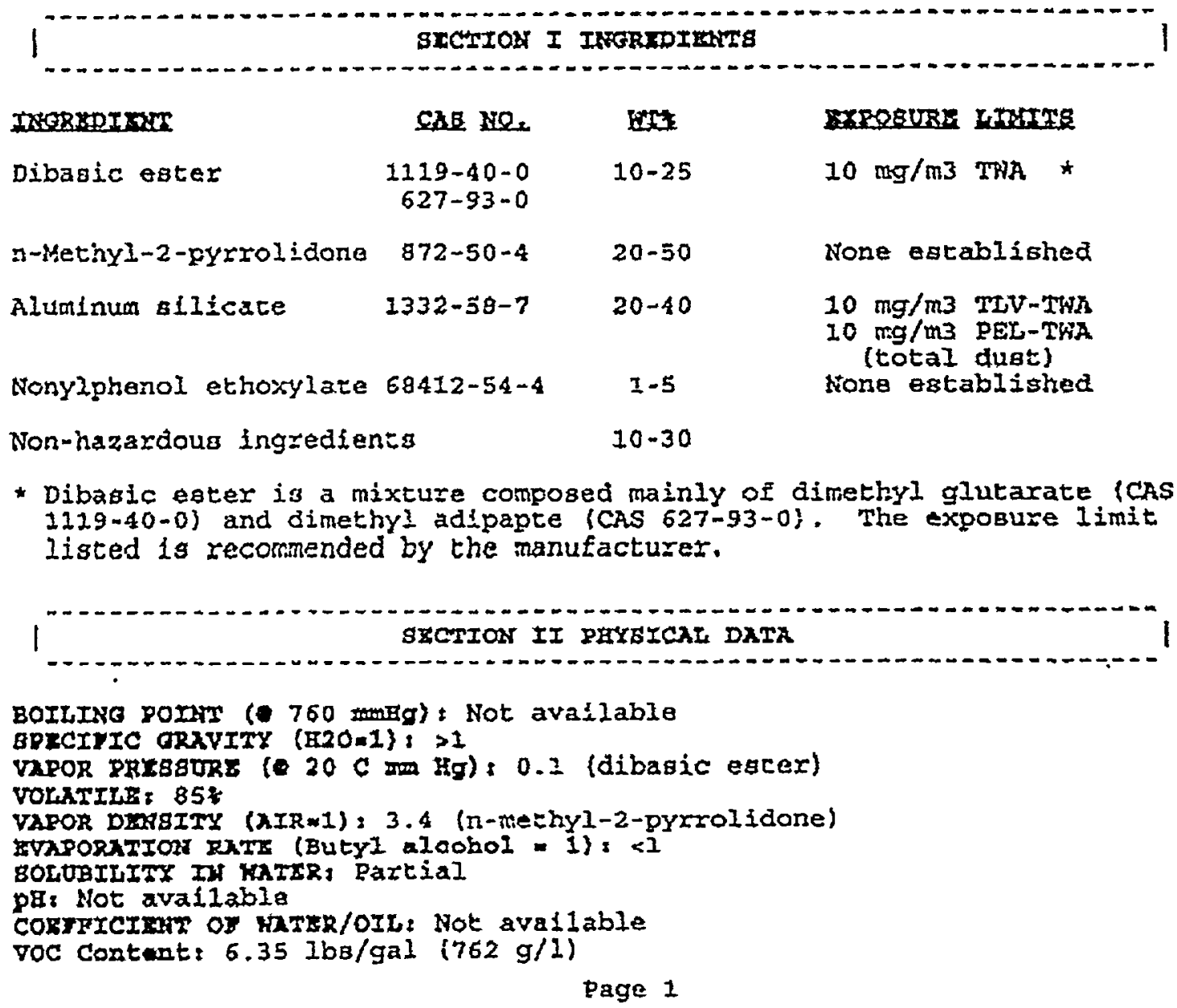


ARPEARANCE AND ODOR, Light brown paste with a glight, sweet odor. There is no odor threshold data availabie for any or the ccmponents.

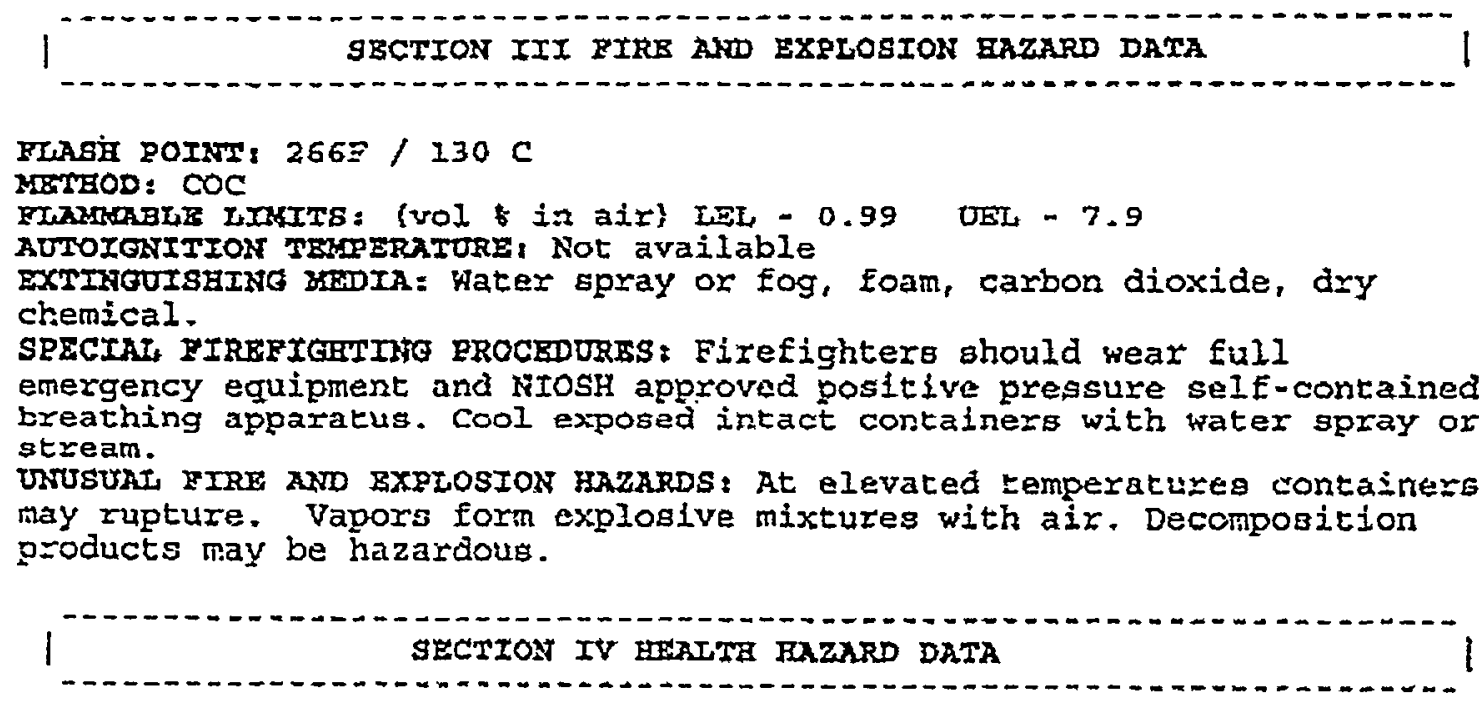

INEALATION: Mjot and vapors may cause irxitation to the eyes, nucous membranes and upper sespiratory tract and blurring of vision.

SNIN CONTACr: May cause ixritation. Prolonged skin contact may cause burna. Hidespread or p:olor:ged contact may cause absorption of $n$-methyl -2-pyrrolidone with symptoms similar to ingestion.

Eys Contac: Vapors msy cause irritation and blurred vision. Direct contace nay calise correal opacity and eüema (swelizng).

INGESTION: May cause gastzcincestinal irritation, vomining, aiarrhea, neadache, and abdominai pain.

CHRORIC BFFECTS OF OYRREXPOSURE: Repeated skin contact may cause dermatitis.

NEDICAI CONDITIONS AGGRAVATZD gY BXPOSUR: Individuals with chronic respiratory or skin diseaseg may be at increased risk Ercra expogure to this material.

TOXXCOLOGY DATA: This produce has not been tesced as a whole. Toxicity values for the components are:

Dibasic ester

n-Methyl-2pyrralidone Mluminum silicate

$$
\begin{aligned}
& \text { a191 } \frac{\mathrm{LD} 50}{\mathrm{mg} / \mathrm{m}} \text { oral rat } \\
& 7000 \mathrm{mg} / \mathrm{kg} \text { oral rat } \\
& 8000 \mathrm{mg} / \mathrm{kg} \text { skin rabbit } \\
& \text { No data available }
\end{aligned}
$$

Page 2

\author{
I, 650 \\ $>21 \mathrm{mg} / \mathrm{l} / \mathrm{h}$ hr rats \\ No data available \\ No data evailable
}


$04 / 15 / 96$

None of the components is listed as a carcinogen of suspect carcinogen by NTP, IARC OY OSHA.

None of the components have been found to be mutagenic.

None of the components are known to cause sensitization in animals or ' humans.

n-Methyl-2-pyrrolidone has been found to cause toxicity in the fetus of laboratory animals exposed during pregnancy. Nore of the components are known to cause adverse reproductive effects or ceratogenic effects in animals or humans.

1 SECTION V ERERORCY and PIRST AIR PROCBDURBS

EYE CONTACT: Immediately flush eye with water for at least 15 minutes while lifting the upper and lower lids. Get imnediate medical attention.

SXIN CONTACr: Wash thoroughly with soap and water until no traces of the chemical remain. Remove contaminated clothing immediately and launder before reuse. Get redlcal attention if irritation develops.

INHAritroN: Renove victim to fresh air. If breathing has stopped give artificial regpiration. If breathing is difticult have qualisied personnel administer oxygen. Get immediate medical attention.

IsGrerIoN: If congcious, give 2 glasses of water to dilute. Do not induce vomiting. Never give anything by mouth to a person who is unconscious or conrulsing. Get immediace medical attention.

| SECTION VI REACTIVITY HARARD DATA

STABIIITY: Thin material is stable. CONDITIONG To AYOID: Not appiicable. IFCOMPXIBILIXI; strong acids, bases, strong oxidizers and reducing agents. ERZRRDOUs DEcossosITIOS PRODUCTs, Thermal decomposition may yield carbon monoxida, carbon dioxide and oxides of nitrogen. HAZARDOUS ROLTHERIZATION: HIII nOt OCCUI. CONDITIONS TO AYOID: Not applicable.

1 SECTION VII BPECIAI PROTECTION IIEORMATION

REBPIRATORY PROTRCTION: None needed undex normal use conditions. IE mist. is genexated and for large jobs where the recommended exposuxe limit may be exceeded use a NIosis approved respirator with organic

page 3 
vapor cartridgeg and a dust/mist pre-filtez. For higher concentratsons (greater that 10 times the recomended exposure 1 imit) an approved eupplied air respirator (with escape bottle if required) or selfcontained breathing apparatus may be required. Selection of respiratory protection depends on the contaminant type, form and concentration. Select in accordance with OSHA 1920.138 and good Industrial Hygiene practice.

VEANILAMION: Good gereral ventilation (equivalent to outdoors) should be adequate under normal conditions. If the recommended exposure limit is exceeded increased techanical ventilation such as local exhaust may be required.

GLOVzs: Butyl rubber or other impervious gloves are required.

PROTRCTIVs chothING: Impervious apron, boots and other clothing are recomended if reeded to prevent contact or if splaghing is possible.

EYE PROTBCrIoN: Chemical safety goggles and/or face ahield required. Do not wear contact lenses.

OTERR PROTBCTYVE EOUIPMENT: FOr Operationa where contact can occus, a bafety shower and an eye wash facflity should be available.

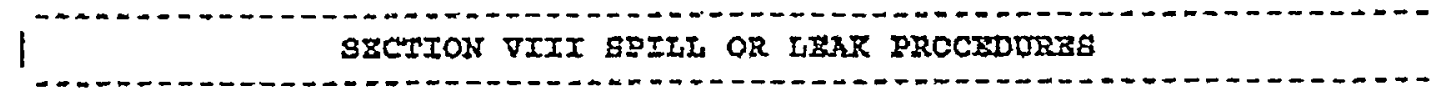

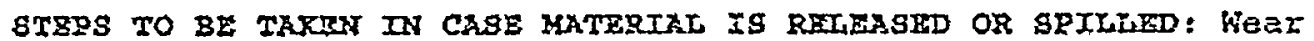
appropriace protective clothing to prevent eye and skin contact. Remove all sources of igniticn. Dike spill and collect into closable containers for disposal with inert aboorient. Wash soill axea with water. Prevent runoff to storn sowerg and ditches leading to natural waterways. Report spill as required by local and federal regulations.

WASTE DISPOgAL HETEOD: Dispcee in accordance with all local, state and federal regulations.

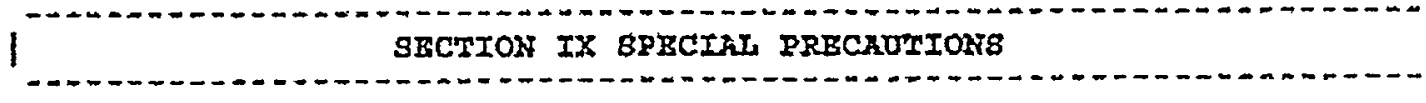

PRECAUTIONS TO DE TAKEN IN HANDLING AND ATORING Frotect containers from physical damage. Store in a cool, weil ventilated area away from oxidizers and other incompatible materialg.

svoid eye and ekin contact. Avoid breathing vapors. Use only with appropriate protective equipment. immediately remove and iaunder contarinated clothing before re-uge. Fash thoroughly after handing and before eating, drinking, smoking or woing tollet facilities.

OTHER DRBCAUTrows: Enpty containers retain product residuea. Follow aII MSDs precautions in handling enpty containers.

Page 4 
1 SECTIOA $X$ REGUTATORY IMTORKATION

DOT INPORHATION: Not regulated

OSH HAZARD CLASSIFICATION: IXXitant, tOXic

SPA GARA 311 HKLARD CLASSIFICATION: Acute health.

WILIS CLASSIFICATION: $\mathrm{D}-2$ Other toxic effecto

TOXIC SUBSTANCES CONRROL ACT: All of the components of this product are listed on the TSCA inventory.

CALIFORAIA PROPOBITION 65: This product containg no California Proposition 65 regulated chemicals.

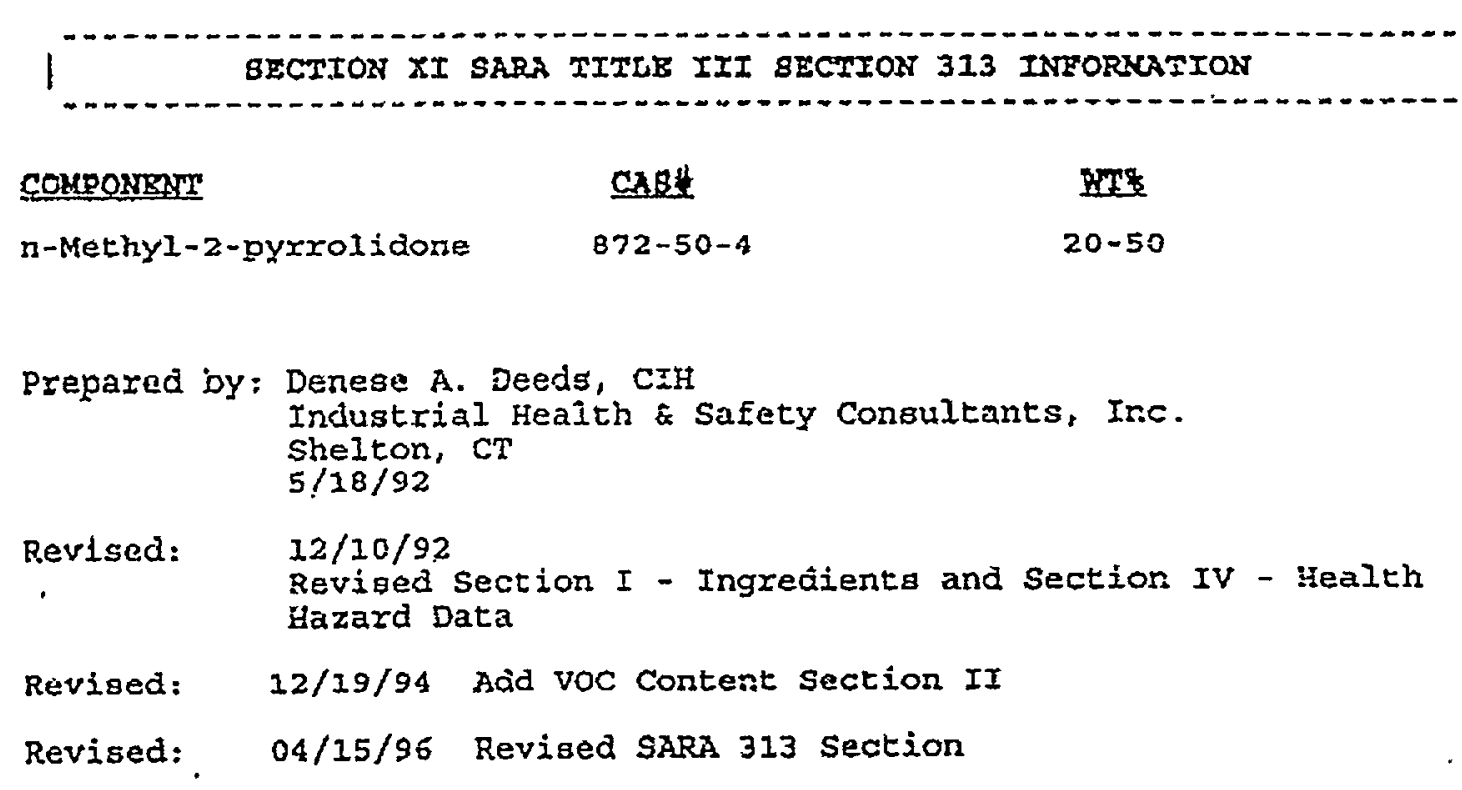

gage 5 


\section{MATERIAL SAFETY DATA SHEET ARMSTr Aluminum Oxide Fiber Media (Type B)}

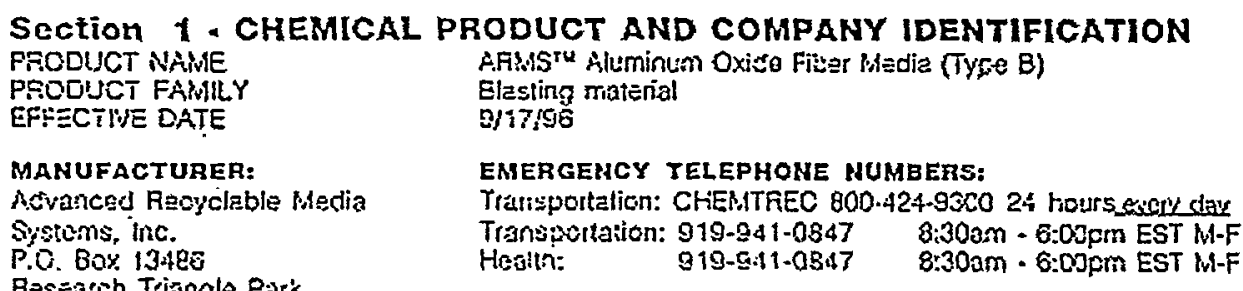

Research Triangle Park.

Notth Casclina 27709

Tel: $918-041-0847$

\section{Section 2 - COMPOSITION, INFORMATION ON INGREDIENTS

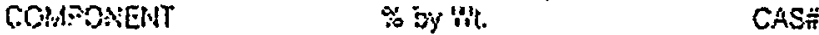 \\ Propeisiary composition:}

Conains alpha alumina and titulun dioxide subject to inhalalion FU and PEL regulations. Sae Section 11 of MISDS.

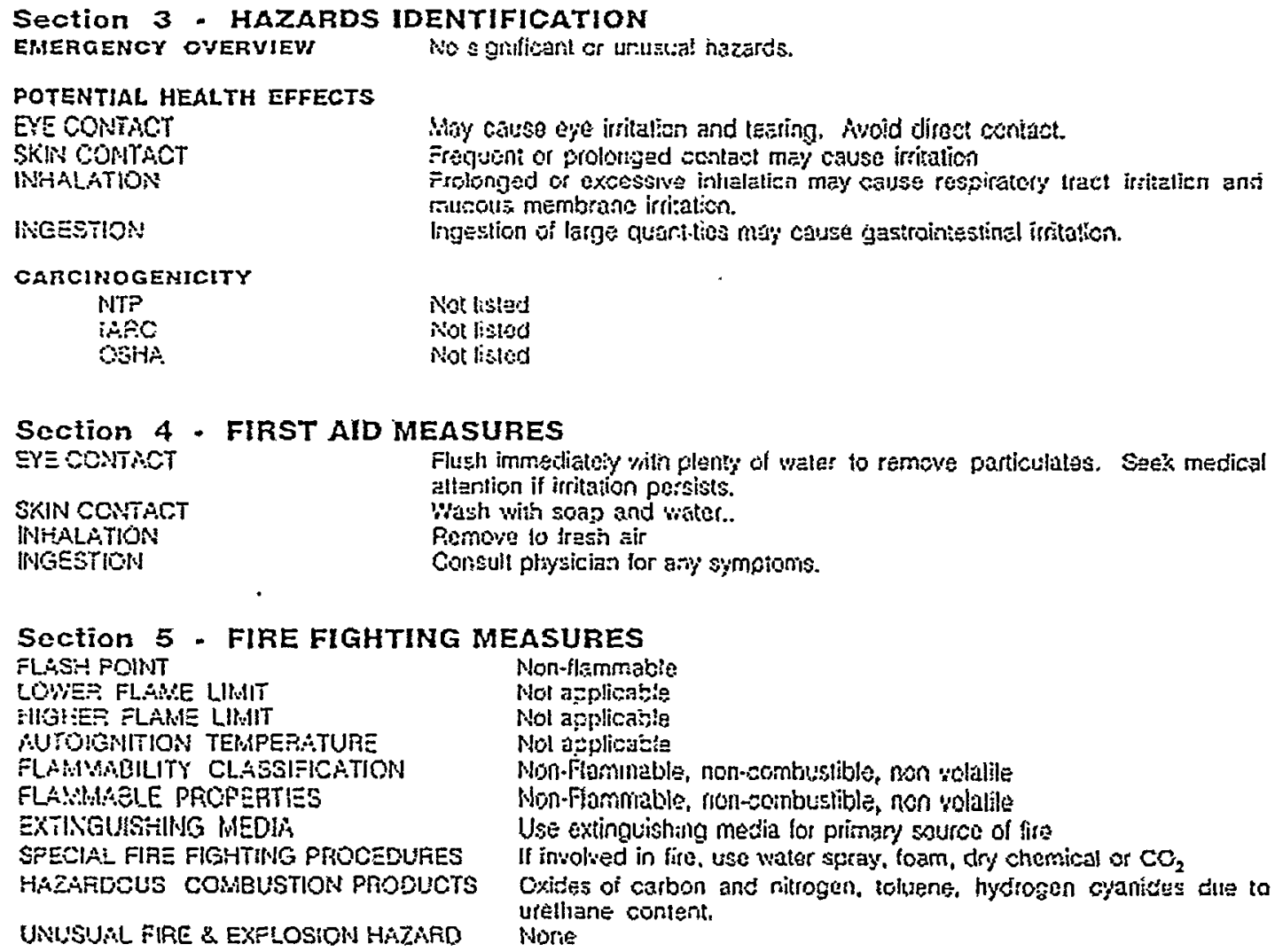

Section 5 . FIRE FIGHTING MEASURES

FLAS:C FOINT

LOWE: FLABE LIMIT

DHGISES FLAWE LIMUIT

AUTOLGNTION TEMPERATURE

FLAMMALITY CLABSIFICATION

FLASAHLELE PACPERTIES

EXINGUAGAIISG WEDIA

SFEOIAI FIRE FIGHTING PROCEDUFES

HAZAFDOUS COABLSTION PRODUCTS

UNUSUJAL FIRE \& EXFLOSION HAZARD

Non-flemmabie

Mal azplicabio

Nol applicaste

Nol atolicsióa

Mon-Fioninable, non-combustible, non volalile

Non-Fammable, ren-sonbustible, non volalile

Use extinguishalg media lot primacy source of tise

If involved in fire, use water spray, foam, dry chemical or $\mathrm{CO}_{2}$

Cxides of carbon and nitrogen. teltene, hydrosen cyanides due to urethane content.

Norie 


\author{
Section 6 - ACCIDENTAL RELEASE MEASURES \\ SFILLS Avoid raising dust Wear NOOSH approved dustimist respiralor. Varultm or sweep up.
}

\title{
Section 7 - HANDLING AND STORAGE
}

HANOUWG Wesh thoroughily siter handing. Use cnly in well yentilated arca. Avoie contace with ewes. STORAGE Avoid high hast--sver $300^{\circ} \mathrm{F}$.

\section{Section 8 - EXPOSURE CONTROLS, PERSONAL PROTECTION}

ENGINEEFIIYG COINTROLS Good general ventiation sheuld be used. Venilation rates should sa

EIE PPOTECTION

SKIN PFIOTECIION matched to conditions.

wros: saley glasses. Aveid eye coniact.

Gloves are recommended.

RESPIRATOPI FROIECTION MOne roquired where adequate ventilation conditions exist. For conditcons imere oxposite to sust is apparent, a dustinist raspirator should be roin.

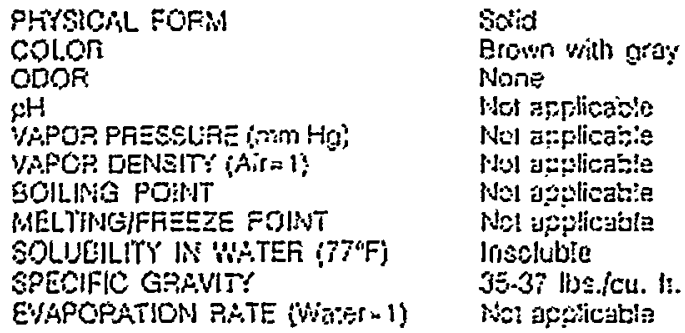

Section to - STABILITY AND REACTIVITY

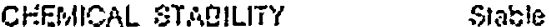

COMEITIONS TO ABYHO Hign iemparatures

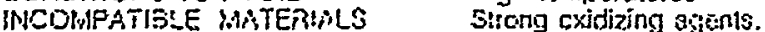

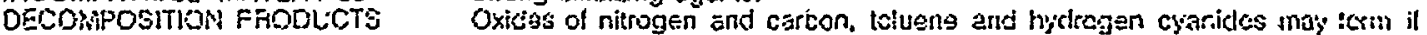

HAZAROOLS FOLYMEAZRTION dscomposed in a tire due to urethane compenent.

Will not occur.

\section{Section 11 . TOXICOLOGICAL INFORMATION}

Ne information syaileblo for product in ita inral form. Prosucl as shipped conicins ro particles al respirable size

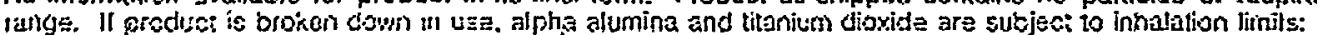
OSHA - PELRHA E mglou.m.

\section{Section 12 - ECOLOGICAL INFORMATION}

No data available on product in ita final form.

Scction 13 . DISPOSAL CONSIDERATIONS

RCRA STATUS

No component is pgulated as hazardous waste under RCRA \{40 CFR 231 . If diecerded in ite purchased forn. this prejuct would not be a hezarticus "ysiste eiller by jisting ar by characteristic. Howevor, under RCAR it it the responsebilily at the prodiset User to delemine. at the ime of discosal.

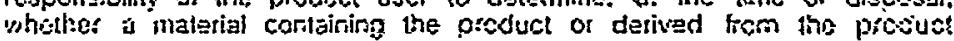
shoald ce classilied es hazirdous wiste. 


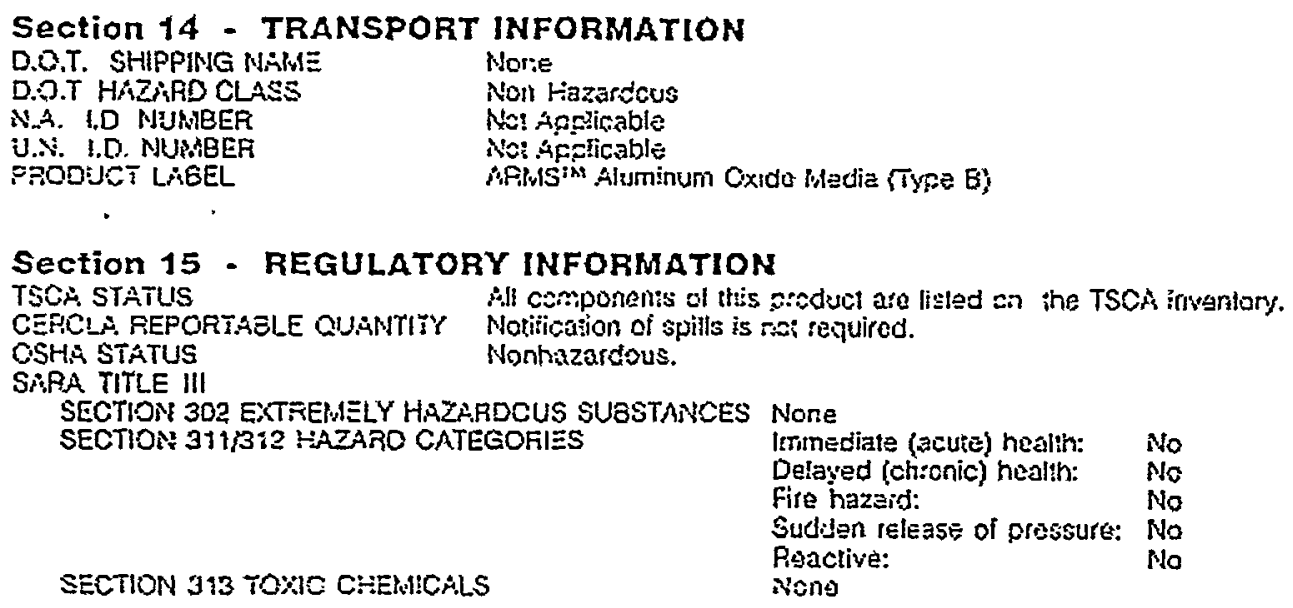

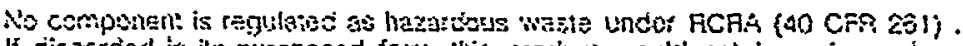
If ciscarced in ils purenazed form, this produes would not ta a hezardsus

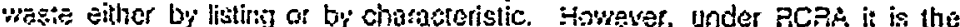
ressonsibility of he pindist use? to cetemine. a: the the of ciisnosal, whethe: a matered ecotaining the produst of derived frort the piesun

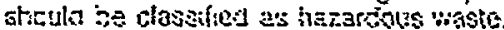

\section{Section 16 - OTHER INFORMATION}

FEASOY FOA ISOUE:

APFFOSIAL DATE:

SUPEFSEDES DATE:

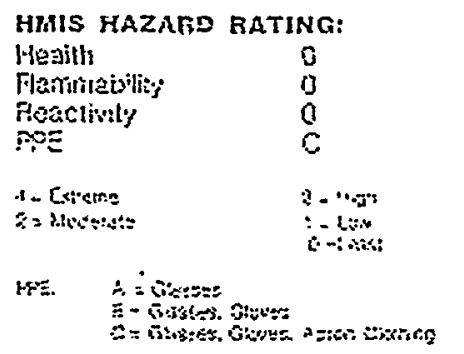

Updi:e of 16 - Cther intomalien

Gi17,

0,20156

\begin{tabular}{|c|c|c|c|c|}
\hline \multicolumn{5}{|c|}{ 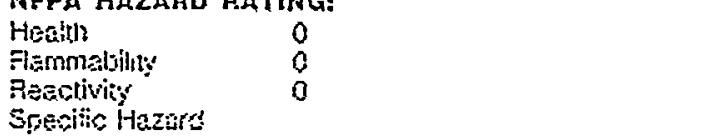 } \\
\hline & 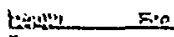 & $m-\infty$ & 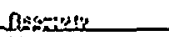 & Somplichysiod \\
\hline $\begin{array}{l}4 \\
\vdots \\
\vdots \\
1 \\
0\end{array}$ & 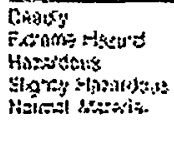 & 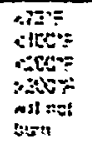 & 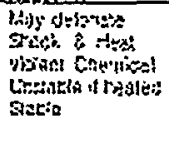 & 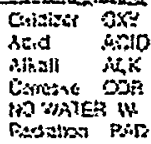 \\
\hline
\end{tabular}

- WIE.

All intc:maticn appearing herein is based upon data obtained frcm manufecturars and or pecognized technical

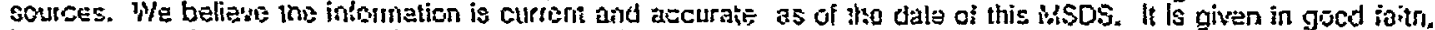
but. no warrenty expressed of tmplied is mats. Since tha use of this iniomotion and the conditicns of the use of

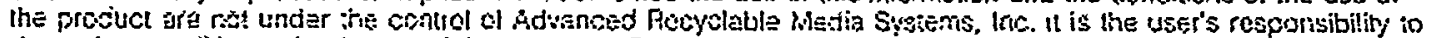
determine cenditions of safe use of the presuet. Flease consult yeur Advanged focyclable Media Systoms, Iric. representative for turther intertiation. 